\title{
Cerebellar Learning Properties Are Modulated by the CRF Receptor
}

\author{
Gili Ezra-Nevo, ${ }^{1,2}{ }^{\oplus}$ Francesca Prestori, ${ }^{3}$ Francesca Locatelli, ${ }^{3}$ Teresa Soda, ${ }^{3,4}$ Michiel M. ten Brinke, ${ }^{5}{ }^{\oplus}$ Mareen Engel, ${ }^{2}$ \\ Henk-Jan Boele, ${ }^{5}$ Laura Botta, ${ }^{3,6}$ Dena Leshkowitz, ${ }^{7}{ }^{\circledR}$ Assaf Ramot, ${ }^{1,2}{ }^{\circledR}$ Michael Tsoory, ${ }^{8}$ Inbal E. Biton, ${ }^{8}$

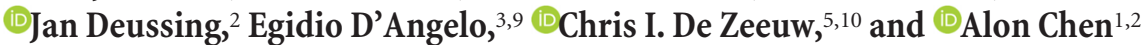 \\ ${ }^{1}$ Department of Neurobiology, Weizmann Institute of Science, Rehovot, 76100, Israel, ${ }^{2}$ Department of Stress Neurobiology and Behavioral Neurogenetics, \\ Max Planck Institute of Psychiatry, Munich, 80804, Germany, ${ }^{3}$ Department of Brain and Behavioral Sciences, University of Pavia, 27100 Pavia, Italy, ${ }^{4}$ Museo \\ Storico della Fisica e Centro Studi e Ricerche Enrico Fermi, 00184 Rome, Italy, ${ }^{5}$ Department of Neuroscience, Erasmus MC, 3000 DR Rotterdam, The \\ Netherlands, ${ }^{6}$ Department of Biology and Biotechnology L. Spallanzani, University of Pavia, 27100 Pavia, Italy, ${ }^{7}$ Department of Biological Services, \\ ${ }^{8}$ Department of Veterinary Resources, Weizmann Institute of Science, Rehovot, 76100, Israel, ${ }^{9}$ Brain Connectivity Center, Istituto Di Ricovero e Cura a \\ Carattere Scientifico C. Mondino, 27100 Pavia, Italy, and ${ }^{10}$ Netherlands Institute for Neuroscience, Royal Dutch Academy of Arts and Science, 1105 BA \\ Amsterdam, The Netherlands
}

Corticotropin-releasing factor $(\mathrm{CRF})$ and its type 1 receptor $\left(\mathrm{CRFR}_{1}\right)$ play an important role in the responses to stressful challenges. Despite the well established expression of $\mathrm{CRFR}_{1}$ in granular cells (GrCs), its role in procedural motor performance and memory formation remains elusive. To investigate the role of $\mathrm{CRFR}_{1}$ expression in cerebellar $\mathrm{GrCs}$, we used a mouse model depleted of $\mathrm{CRFR}_{1}$ in these cells. We detected changes in the cellular learning mechanisms in GrCs depleted of $\mathrm{CRFR}_{1}$ in that they showed changes in intrinsic excitability and long-term synaptic plasticity. Analysis of cerebella transcriptome obtained from KO and control mice detected prominent alterations in the expression of calcium signaling pathways components. Moreover, male mice depleted of $\mathrm{CRFR}_{1}$ specifically in $\mathrm{GrCs}$ showed accelerated Pavlovian associative eye-blink conditioning, but no differences in baseline motor performance, locomotion, or fear and anxiety-related behaviors. Our findings shed light on the interplay between stress-related central mechanisms and cerebellar motor conditioning, highlighting the role of the CRF system in regulating particular forms of cerebellar learning.

Key words: cerebellum; CRF; CRFR1; eyeblink conditioning; granule cells

Significance Statement

Although it is known that the corticotropin-releasing factor type 1 receptor $\left(\mathrm{CRFR}_{1}\right)$ is highly expressed in the cerebellum, little attention has been given to its role in cerebellar functions in the behaving animal. Moreover, most of the attention was directed at the effect of CRF on Purkinje cells at the cellular level and, to this date, almost no data exist on the role of this stress-related receptor in other cerebellar structures. Here, we explored the behavioral and cellular effect of granular cell-specific ablation of CRFR . We found a profound effect on learning both at the cellular and behavioral levels without an effect on baseline motor skills.

\section{Introduction}

Physical or psychological challenge perceived by the organism is followed by a series of sensory, motor, neuroendocrine and cog-

Received Aug. 18, 2015; revised April 17, 2018; accepted April 26, 2018.

Author contributions:G.E.-N., A.R., J.M.D., E.D., C.I.D.Z., and A.C. designed research; G.E.-N., F.P., F.L., T.S., M.t.B., M.E., H.-J.B., L.B., A.R., M.T., and I.E.B. performed research;G.E.-N. contributed unpublished reagents/analytic tools; G.E.-N., F.P., F.L., T.S., M.t.B., M.E., H.-J.B., L.B., D.L., A.R., M.T., I.E.B., and J.M.D. analyzed data; G.E.-N. and A.C. wrote the paper.

This work was supported by an FP7 Grant from the European Research Council (Grant 260463 to A.C.); the Israel Science Foundation (Research Grant 1565/15 to A.C.); the ERANET Program, supported by the Chief Scientist Office of the Israeli Ministry of Health (A.C.); the Federal Ministry of Education and Research (Grant 01KU1501A to A.C.); research support from Roberto and Renata Ruhman (A.C.); research support from Bruno and Simone Licht; I-CORE Program of the Planning and Budgeting Committee and the Israel Science Foundation (Grant 1916/12 to A.C.); the Nella and Leon Benoziyo Center for Neurological Diseases (A.C.); the Henry Chanoch Krenter Institute for Biomedical nitive modifications (Joëls and Baram, 2009). These modifications are generally aimed at increasing the organism's chances for

Imaging and Genomics (A.C.); the Perlman Family Foundation founded by Louis L. and Anita M. Perlman (A.C.); the Adelis Foundation (A.C.); the Irving I. Moskowitz Foundation (A.C.); and the Marc Besen and the Pratt Foundation. C.I.D.Z. is supported by the Dutch Organization for Medical Sciences (ZonMw), Life Sciences (ALW), Senter (NeuroBasic), the ERC-advanced and ERC-POC of the European Community. A.C. is the head of the Max Planck Society Weizmann Institute of Science Laboratory for Experimental Neuropsychiatry and Behavioral Neurogenetics. We thank Sharon Ovadia for devoted assistance with animal care.

The authors declare no competing financial interests.

Correspondence should be addressed to either of the following; Alon Chen, Department of Neurobiology, Weizmann Institute of Science, Rehovot, 76100, Israel, E-mail: alon.chen@weizmann.ac.il; or Chris I. De Zeeuw, Department of Neuroscience, Erasmus MC, 3000 DR, Rotterdam, the Netherlands, E-mail: c.dezeeuw@erasmusmc.nl.

DOI:10.1523/JNEUROSCI.3106-15.2018

Copyright $\odot 2018$ the authors $\quad 0270-6474 / 18 / 386751-15 \$ 15.00 / 0$ 
survival (Joëls and Baram, 2009; Santarelli et al., 2014). Corticotropin releasing factor (CRF) and its major receptor, CRF receptor type $1\left(\mathrm{CRFR}_{1}\right)$, play an important and well established role in the response to stressful challenges (Koob and Heinrichs, 1999; Heinrichs and Koob, 2004; Joëls and Baram, 2009; Sztainberg and Chen, 2012; Henckens et al., 2016). Depending on the specific stressor and demand, CRF and its receptors induce different responses to promote appropriate coping (Farook et al., 2004; Sztainberg and Chen, 2012; Henckens et al., 2016; Fadok et al., 2017). When considering learning and memory, it is evident that stress can either increase or decrease learning depending on the procedure (Joëls et al., 2006; Joëls and Baram, 2009). Accordingly, CRF/CRFR ${ }_{1}$ have been shown to support learning (Sztainberg and Chen, 2012) or disrupt learning (Wang et al., 2011; Santarelli et al., 2014) depending on the behavioral procedure and brain region involved.

Cerebellar granular cells (GrCs), which are known to play a pivotal role in cerebellar learning (Hansel et al., 2001; Gao et al., 2012; Galliano et al., 2013; Mapelli et al., 2016; Giovannucci et al., 2017), show a prominent CRFR 1 expression (Sánchez et al., 1999; Van Pett et al., 2000; Justice et al., 2008; Refojo et al., 2011; Kühne et al., 2012), whereas CRF is expressed in the fibers innervating them; that is, the mossy fibers (Olschowka et al., 1982; Merchenthaler, 1984; Cummings et al., 1988; Foote and Cha, 1988; Errico and Barmack, 1993; Bishop et al., 2000; Chen et al., 2000). Although the interaction between the CRF system and cerebellar learning has been studied previously, our understanding remains limited due to a lack of region or cell-type-specific approaches (i.e., intracerebroventricular CRF injections; Servatius et al., 2005). At the cellular level, only the specific effect of CRF on Purkinje cells (PCs) has been investigated (Bishop, 1990; Miyata et al., 1999; Swinny et al., 2004; Schmolesky et al., 2007; Libster et al., 2015). Therefore, the involvement of the CRF family in cerebellar learning at the cellular and behavioral levels, particularly relating to $\mathrm{GrC}$ function, has been neglected.

In this work, we aimed to elucidate the role of $\mathrm{CRFR}_{1}$ specifically in cerebellar GrCs. For this purpose, we generated a $\mathrm{GrC}$-specific $\mathrm{CRFR}_{1}$ conditional $\mathrm{KO}\left(\mathrm{CRFR}_{1}{ }^{\mathrm{cKO}}\right)$ mouse using the Cre-lox system. Electrophysiological recordings of GrCs in $\mathrm{CRFR}_{1}{ }^{\mathrm{cKO}}$ and control mice revealed changes in excitability and theta-burst stimulation (TBS), inducing long-term potentiation (LTP) in control GrCs and generating long-term depression (LTD) in GrCs depleted of $\mathrm{CRFR}_{1}$. Analysis of the transcriptome of cerebella obtained from $\mathrm{KO}$ and control mice revealed differences in the expression of calcium signaling components. When tested on the eye-blink conditioning (EBC) procedure, mice depleted of $\mathrm{CRFR}_{1}$ showed accelerated learning compared with controls, whereas their general level of motor performance was unaffected. We further tested the mice for anxiety-like behavior and anxietyrelated learning and did not detect any differences between the groups. Together, these results link $\mathrm{GrC} \mathrm{CRFR}_{1}$ and learning properties at both the cellular and behavioral level.

\section{Materials and Methods}

\section{Animals}

All animals were housed in a temperature-controlled room $\left(22 \pm 1^{\circ} \mathrm{C}\right)$ on a reverse $12 \mathrm{~h}$ light/dark cycle with food available ad libitum. Adult (12-20 weeks old) male mice and age matched littermates were used for all experiments, excluding electrophysiology experiments, in which both sexes were used. Behavioral tests were performed during the dark phase of the circadian cycle after at least $1 \mathrm{~h}$ of habituation to the test room unless stated otherwise. All experimental protocols were approved by the Institutional Animal Care and Use Committee of the Weizmann Institute of Science.
Reporter lines. Mice expressing GFP under the $\mathrm{CRFR}_{1}$ promoter $\left(\mathrm{CRFR}_{1}{ }^{\mathrm{GFP}}\right.$ ) (Justice et al., 2008) were crossed with mice expressing Crerecombinase under the CRF promoter (CRH-ires-Cre; The Jackson Laboratory; http://jaxmice.jax.org/strain/012704.html; RRID:IMSR_JAX: 012704) and Ai9 reporter mice, in which tdTomato expression is Cre dependent (Ai9) (Madisen et al., 2010); The Jackson Laboratory; http:// jaxmice.jax.org/strain/007909.html; RRID:IMSR_JAX:007909).

$G r C-C R F R_{1}{ }^{c K O}$ mice. Mice lacking $\mathrm{CRFR}_{1}$ were generated by crossing mice carrying a conditional allele of CRFR1 with mice expressing Crerecombinase knocked into the GABA-A $\alpha 6$ subunit promoter $(\Delta \alpha 6$-Cre; obtained from the Mutant Mouse Resource \& Research Centers; https:// www.mmrrc.org/catalog/sds.php?mmrrc_id=15968; RRID:IMSR_JAX: 007909) (Aller et al., 2003). Mouse genotype was determined using PCR. Floxed $\mathrm{CRFR}_{1}$ (i.e., $\left.\mathrm{CRFR}_{1}{ }^{\text {flox/flox }}\right)$, Cre-positive $\left(\alpha 6-\mathrm{Cre}^{+/-}\right)$mice served as controls for the electrophysiology experiments; for the behavior experiments, only $\mathrm{CRFR}_{1}$ flox/flox and GrCs-CRFR ${ }_{1}{ }^{\mathrm{cKO}}$ mice were used. For $\mathrm{CRFR}_{1} \Delta \alpha 6$-cre colocalization, $\mathrm{CRFR}_{1}{ }^{\mathrm{GFP}}$ mice were crossbred with $\Delta \alpha 6$-cre and Ai9 mice.

\section{Slice preparation and solutions}

All experiments were performed according to the guidelines established by the institution's animal welfare committee. We performed whole-cell patch-clamp recordings from $\mathrm{GrCs}$ in acute cerebellar slices as reported previously (Prestori et al., 2008, 2013; Sgritta et al., 2017) from postnatal day 18 (P18) to P22 mice. Briefly, mice were killed by decapitation after anesthesia with halothane. The cerebellum was gently removed and the vermis was isolated and fixed on the stage of a vibroslicer (VT1200S; Leica) with cyano-acrilic glue. Acute $220-\mu \mathrm{m}$-thick slices were cut in parasagittal plane in cold Kreb's solution containing the following (in $\mathrm{mm}): 120 \mathrm{NaCl}, 2 \mathrm{KCl}, 1.2 \mathrm{MgSO}_{4}, 26 \mathrm{NaHCO}_{3}, 1.2 \mathrm{KH}_{2} \mathrm{PO}_{4}, 2 \mathrm{CaCl}_{2}$, and 11 glucose, $\mathrm{pH} 7.4$ when equilibrated with $95 \% \mathrm{O}_{2}-5 \% \mathrm{CO}_{2}$, and maintained at room temperature before being transferring to a recording chamber mounted on the stage of an upright microscope (Axioskop 2 FS; Zeiss). The slices were perfused with Kreb's solution and maintained at $32^{\circ} \mathrm{C}$ with a Peltier feedback device (TC-324B; Warner Instruments). For recordings, Kreb's solution was added with the $\mathrm{GABA}_{\mathrm{A}}$ receptor antagonist SR95531 $(10 \mu \mathrm{M})($ Abcam). Recordings were performed with Multiclamp 700B [-3 dB; cutoff frequency (fc),10 kHz], sampled with Digidata 1550 interface, and analyzed offline with pClamp10 software (Molecular Devices). Patch pipettes were pulled from borosilicate glass capillaries (Sutter Instruments) and had a resistance of 7-9 $\mathrm{M} \Omega$ before seal formation when filled with the intracellular solution containing the following (in $\mathrm{mm}$ ): 126 potassium gluconate, $4 \mathrm{NaCl}, 5 \mathrm{HEPES}, 15$ glucose, $1 \mathrm{MgSO}_{4} \cdot 7 \mathrm{H}_{2} \mathrm{O}, 0.1$ BAPTA-free, 0.05 BAPTA-Ca ${ }^{2+}, 3 \mathrm{Mg}^{2+}$. ATP, and $0.1 \mathrm{Na}^{+}$-GTP, pH 7.2 adjusted with $\mathrm{KOH}$. The liquid junction potential (ELJ) between the bath and pipette solution was measured according to Neher (1992). Correction for ELJs in patch-clamp experiments was $\sim 10 \mathrm{mV}$. ELJ has not been subtracted from the membrane potential measurements.

\section{Whole-cell recording properties}

The cerebellar $\mathrm{GrC}$ is electrotonically compact and can be treated as a simple RC system in which relevant parameters can be extracted by analyzing passive current relaxation induced by $10 \mathrm{mV}$ hyperpolarizing steps from a holding potential of $-70 \mathrm{mV}$. The voltage-clamp time constant, $\tau_{\mathrm{vc}}$, was estimated from biexponential fitting to current transients elicited by voltage steps. The $3 \mathrm{~dB}$ cutoff frequency of the electrode cell system was calculated as fvc $=\left(2 \pi \cdot \tau_{\mathrm{vc}}\right)^{-1}$. Membrane capacitance $\left(C_{\mathrm{m}}\right)$ was measured from the capacitive charge (the area underlying current transient), membrane resistance $\left(R_{\mathrm{m}}\right)$ was obtained from the steady-state current flow, also yielding series resistance $\left(R_{\mathrm{s}}\right)=\tau_{\mathrm{vc}} / C_{\mathrm{m}}$. Data are reported in Table 1 . These values did not change significantly after $30 \mathrm{~min}$ at testing recording stability.

\section{GrC excitability}

After switching to current clamp, intrinsic excitability was investigated by setting resting membrane potential at $-80 \mathrm{mV}$ and injecting $2 \mathrm{~s}$ current steps (from -8 to $44 \mathrm{pA}$ in $4 \mathrm{pA}$ increment). Action potentials in GrCs show a prepotential followed by the upstroke (D'Angelo et al., 1995, 1998; Rossi et al., 1998; Armano et al., 2000; Prestori et al., 2008). 
Table 1. Properties of whole-cell recordings in mice GrCs

\begin{tabular}{lccr}
\hline & $\begin{array}{l}\text { Control flox } \\
(n=13)\end{array}$ & $\begin{array}{l}\text { Control Cre } \\
(n=10)\end{array}$ & \multicolumn{1}{c}{$\begin{array}{c}\mathrm{CRFR}_{1}{ }^{\mathrm{CKO}} \\
(n=10)\end{array}$} \\
\hline$R_{\mathrm{m}}(\mathrm{G} \Omega)$ & $1.5 \pm 0.2$ & $1.3 \pm 0.2$ & $1.8 \pm 0.3$ \\
$C_{\mathrm{m}}(\mathrm{pF})$ & $3.1 \pm 0.2$ & $3.2 \pm 0.2$ & $2.9 \pm 0.3$ \\
$R_{\mathrm{s}}(\mathrm{M} \Omega)$ & $27.6 \pm 2.5$ & $28.1 \pm 6.0$ & $26.4 \pm 2.4$ \\
$\mathrm{f}_{\mathrm{V}}(\mathrm{KHz})$ & $2.1 \pm 0.2$ & $2.4 \pm 0.3$ & $2.3 \pm 0.2$ \\
$\mathrm{~T}_{\mathrm{V}}(\mu \mathrm{s})$ & $88.2 \pm 10.0$ & $89.2 \pm 15.2$ & $79.3 \pm 11.5$ \\
$V_{\mathrm{m}}(\mathrm{mV})$ & $-49.9 \pm 3.1$ & $-51.6 \pm 2.6$ & $-48.8 \pm 2.8$ \\
\hline
\end{tabular}

The data were obtained using K-gluconate intracellular solution and analyzing current transients elicited by $10 \mathrm{mV}$ voltage-clamp steps delivered from the holding potential of $-70 \mathrm{mV}$.

Action potential threshold was measured along the raising phase of membrane potential responses to step current injection.

The amplitude of the action potential overshoot was estimated as the maximum reached potential. The amplitude of the action potential AHP was estimated as the lowest potential after the upstroke. Action potential frequency was measured by dividing the number of spikes by the current injected duration. Action potential instantaneous frequency was calculated as the inverse of the interval time from the previous spike.

\section{Synaptic currents}

Mossy fiber stimulation was performed with a bipolar tungsten electrode (Clark Instruments) via stimulus isolation unit. The stimulation electrode was placed over the fiber bundle in the cerebellar lamina to stimulate the mossy fibers and $200 \mu$ s step current pulses were applied at the frequency of $0.33 \mathrm{~Hz}$ (test frequency). After evoking EPSCs at $-70 \mathrm{mV}$ at the test frequency for $10 \mathrm{~min}$ (control period), the recording was switched to current clamp. LTP induction protocol consisted of four $100 \mathrm{~ms} / 100 \mathrm{~Hz}$ bursts repeated every $250 \mathrm{~ms}$ (TBS) from the potential of $-50 \mathrm{mV}$ (Armano et al., 2000; Prestori et al., 2008). Long-term synaptic plasticity changes were measured after $20 \mathrm{~min}$. Then, after reestablishing voltage clamp at $-70 \mathrm{mV}$, stimulation was restarted at test frequency. EPSCs were digitally filtered at $1.5 \mathrm{kHz}$ and analyzed offline. If $R_{\mathrm{s}}$ changed by $>20 \%$ over the course of the experiment, then the results were not considered further.

\section{Immunohistochemistry}

Mice were killed using an intraperitoneal injection of sodium thiopental and intracardially perfused with PBSx1 followed by 4\% PFA in PBSx1. Brains were fixed in 4\% PFA 30\% sucrose solution and serially sectioned to 30 or $50 \mu \mathrm{m}$ using a microtome (Leica Microsystems).

Brain slices were blocked for $1 \mathrm{~h}$ with PBS containing 20\% normal horse serum and $0.3 \%$ Triton X-100 followed by incubation overnight with monoclonal mouse anti-Calbindin-D-28K antibody (C9848; Sigma-Aldrich; RRID:AB_476894) and rabbit anti-GFP antibody (ab6556; Abcam; RRID:AB_305564). Primary antibodies were diluted 1:200. Slices were washed and incubated with M.O.M. anti-mouse biotinylated antibody (Vector Laboratories; RRID:AB_2336833), followed by a $2 \mathrm{~h}$ incubation with anti-rabbit Alexa Fluor 488 and/or streptavidinconjugated Alexa Fluor 647 (A-21206, A-31573; Life Technologies; RRID:AB_2535792, RRID:AB_2536183). Slices were then washed and mounted on gelatin-coated slides. Imaging was performed using a confocal microscope (LSM 700; Zeiss).

\section{Golgi stain}

Cerebella were dissected and processed according to manufacturer's instructions (NeuroTechnologies). Sagittal $50 \mu \mathrm{m}$ sections were collected and stained according to the manufacturer's instructions. Images were collected with a light microscope and analyzed using ImageJ.

\section{Modified CLARITY and whole-brain imaging}

The brain-clearing protocol was based on a modified CLARITY protocol (Ye et al., 2016) with the following changes. Briefly, CRF-Cre $\times$ Ai9 mice were transcardially perfused with PBSx1 followed by ice-cold $4 \%$ PFA. Brains were postfixed in $4 \%$ PFA overnight at $4^{\circ} \mathrm{C}$ and then transferred to $1 \%$ hydrogel solution ( $1 \%$ acrylamide, $0.125 \%$ bis-acrylamide, $4 \%$ PFA, $0.025 \%$ VA-044 initiator, in PBSx1) for $72 \mathrm{~h}$. Brains were then degassed and polymerized for $5 \mathrm{~h}$ at $37^{\circ} \mathrm{C}$. Next, whole brains were cut into 2 hemispheres and washed with $200 \mathrm{~mm} \mathrm{NaOH}$-Boric buffer, $\mathrm{pH}$ 8.5, containing $8 \%$ SDS for $12 \mathrm{~h}$. Brain hemispheres were transferred to a clearing device built from a temperature-control circulator containing clearing solution (100 mM Tris-boric buffer, $8 \%$ SDS at $37-40^{\circ} \mathrm{C}$ ). Twelve days later, the samples were washed in PBST $(0.2 \%$ Triton X-100) for at least $48-72 \mathrm{~h}$ at $37^{\circ} \mathrm{C}$. Brain hemispheres were incubated for $2-4 \mathrm{~d}$ in a refractive index matching solution (RIMS;(Treweek et al., 2015)) containing phosphate buffer and Histodenz (Sigma-Aldrich). Brain hemispheres were then imaged using a light-sheet microscope (Ultramicroscope II; LaVision BioTec). Briefly, brain hemispheres were mounted on a holder and the imaging chamber was filled with $100 \mathrm{ml}$ of RIMS. Imaging was done using a $2 \times / 0.5$ numerical aperture objective at $1 \times$ magnification while both light sheets were illuminating the sample, and the Z-step was set to $5 \mu \mathrm{m}$. Then, 16-bit TIFF files were stitched and visualize using Vision4D software (arivis).

\section{$R N A$ extraction and $q R T-P C R$}

Immediately after decapitation, the brain was removed and hippocampi (bilateral) and cerebella were dissected and stored at $-80^{\circ} \mathrm{C}$ until use. RNA extraction was performed using TRI Reagent ${ }^{\circledR}$ according to the manufacturer's protocol (Sigma-Aldrich). To avoid genomic DNA contamination, RNA samples were treated with Turbo Dnase (Life Technologies) and then reverse transcribed to generate complementary DNA (cDNA) using a high-capacity RT kit (Applied Biosystems). cDNA samples were then analyzed using the TaqMan PCR kit or cyber assay according to the manufacturer's guidelines in StepOne (Applied Biosystems). $\mathrm{CRFR}_{1}$-specific primers provided with TaqMan were used (Life Technologies catalog \#4351372), with the expression of hypoxanthine phosphoribosyltransferase (HPRT; Life Technologies catalog \#4453320) used as an internal control. Atp2b4 primers forward: CATCATCGGAGTCACT GTACTGGTA, reverse: GGACCAAGTTGTTGTCCTTCATC, Gabra6 forward: CTTGCTGGAAGGCTATGACAAC, reverse: AAGTCTGGC GGAAGAAAACAT, and HPRT: forward: GCAGTACAGCCCCAAAAT GG, reverse: GGTCCTTTTCACCAGCAAGCT.

\section{RNA sequencing}

After homogenization of freshly dissected cerebella using a Bullet Blender (Next Advance) and isopropanol precipitation, total RNA was isolated using TRIzol (Invitrogen) according to the manufacturer's instructions. Residual genomic DNA was removed using the Turbo DNAfree kit (Invitrogen). RNA integrity and absence of DNA were confirmed by Bioanalyzer RNA Nano chips (Agilent, RIN > 9.3) and Qubit DNA High Sensitivity kit, respectively. Sequencing libraries were prepared using the Illumina TruSeq Stranded mRNA Library Preparation HT Kit following the standard protocol starting from $4 \mu \mathrm{g}$ of total RNA using 11 cycles of PCR amplification. Sequencing was performed on 2 lanes of an Illumina HiSeq4000 multiplexing all samples. STAR version 2.5.2b (Dobin et al., 2013) was used to align and count the trimmed reads to mm10 genome and to count refSeq annotation genes (downloaded from iGenomes). DESeq2 was used to normalize and detect differentially expressed genes when comparing six control mice with six CRFR $1^{\text {cKO }}$ mice. For the DESeq (Love et al., 2014) model, only genes with a total of five counts in all samples were used (18394 genes). Of these, 10 genes were found to have an adjusted $p$-value (Benjamini and Hochberg) lower than 0.05 and an absolute log fold change $>0.4$. Ingenuity Pathway Analysis (IPA) 7.1 Software (Ingenuity Systems; RRID:SCR_008653) was used to examine altered canonical pathways.

\section{Western blot}

Cerebella dissections were lysed in lysis buffer containing $25 \mathrm{~mm}$ Tris$\mathrm{HCl}, \mathrm{pH} 7.4,150 \mathrm{~mm} \mathrm{KCl}, 1.5 \mathrm{~mm} \mathrm{MgCl} 2,1 \%$ (w/v) glycerol, and 1\% $(\mathrm{w} / \mathrm{v})$ NP40 plus protease inhibitors. Lysates were subjected to gel electrophoresis on $10 \%$ SDS-PAGE and separated proteins were transferred onto nitrocellulose membranes and probed with AB5453 Rabbit AntiGABA A Receptor $\alpha 6$ Antibody (Merck-Millipore; RRID:AB_177478) or Anti-Calcium Pump PMCA4 ATPase antibody [JA9] (ab2783; Abcam; RRID:AB_303296). Membranes were then incubated with HRP-conjugated anti-rabbit secondary antibody. Thereafter, the blots were stripped and reprobed with anti- $\beta$-actin (A1978; Sigma-Aldrich; RRID:AB_476692) or GAPDH (ab8245; Abcam; RRID:AB_2107448). 


\section{Behavioral procedures}

Rota-rod. Mice were placed on a standard rota-rod apparatus (San Diego Instruments) with the speed increasing linearly from 0 to $40 \mathrm{rpm}$ over a 4 min period or over a $2 \mathrm{~min}$ period. Mice had a $5 \mathrm{~min}$ habituation on the apparatus, which was immediately followed by 4 consecutive trials on the rotating cylinder. Mice were given a 2 min break between trials. Sum of latencies to fall off the rotating cylinder and maximal velocity reached in the session were calculated.

Treadmill. The treadmill apparatus (Panlab; Harvard Apparatus; LE8710M) consists of a rolling belt with adjustable speed and acceleration. The apparatus provides an electrical shock from a grid situated at the end of the rolling belt. We created a treadmill protocol that consisted of a habituation day followed by a test day. On the habituation day, mice were familiarized for $10 \mathrm{~min}$ with the shocker operating at $0.2 \mathrm{~mA}$ while the treadmill belt was not moving. On the next day, mice were subjected to the treadmill accelerating according to a crescendo protocol: during the first $10 \mathrm{~min}$, the speed increased from $0.1 \mathrm{~m} / \mathrm{h}$ to $0.18 \mathrm{~m} / \mathrm{h}$; at the next $5 \mathrm{~min}$, the speed increased from 0.18 to $0.19 \mathrm{~m} / \mathrm{h}$. The number of falls onto the grid per mouse was counted.

Home cage locomotion. Locomotion was assessed using the InfraMot system (TSE Systems). Mice were housed individually for $72 \mathrm{~h}$, of which the first $24 \mathrm{~h}$ were considered habituation to the individual housing conditions. Measurements of general locomotion consisted of the averages of two light and two dark cycles in the last $48 \mathrm{~h}$ collected at $30 \mathrm{~min}$ intervals.

Delayed EBC. EBC is a classical conditioning task in which animals learn to associate a neutral conditioned stimulus (CS; green LED light) with an unconditioned stimulus (US; air puff or to the cornea) (De Zeeuw and Yeo, 2005). Repeated CS-US pairings result in the acquisition of a CR to the LED CS, which is an eye blink that is well timed to the onset of the air puff US. Delayed EBC, during which the CS co-terminates with the US presentation, is presumably largely encoded in the cerebellum (Koekkoek et al., 2003). Mice were equipped with a cranial pedestal for the purpose of head fixation as described previously (Boele et al., 2013). After a recovery period of 1 week, mice were subjected to an EBC procedure, in which eyelid movement was recorded using the magnetic distance measurement technique (MDMT) (De Zeeuw et al., 1998; Koekkoek et al., 2002). Before training, mice were initially subjected to three consecutive habituation sessions. Mice were placed and head fixed on a feely moving treadmill. A minuscule magnet $(1.5 \times 0.7 \times 0.5 \mathrm{~mm})$ was place on their lower eyelid and a magnet-sensitive chip was placed in proximity to the magnet to detects its movements (see Fig. $6 a, b$; for more details, see Koekkoek et al., 2002). Mice then underwent daily training sessions for $10 \mathrm{~d}$ consisting of 100 trials each spaced $10 \mathrm{~s}$ apart. Each trial started with $500 \mathrm{~ms}$ pre-CS period (baseline), followed by a 330 or $280 \mathrm{~ms}$ (see Fig. 6 and Fig. 6-2, available at https://doi.org/10.1523/ JNEUROSCI.3106-15.2018.f6-2) light CS presentation paired with a coterminating $30 \mathrm{~ms}$ mild corneal air puff US, yielding an interstimulus interval of 300 or $250 \mathrm{~ms}$. Individual eye-blink traces were analyzed using MATLAB (RRID:SCR_001622). First, trials were normalized to values $0-100$. For each session, SD of the baseline period (500 ms pre-CS period) was calculated and trials that had baseline $\mathrm{SD}>3$-fold larger than the session SD were excluded. CR and eye position analysis for training sessions was as follows: in valid trials, eyelid movements in the last $20 \%$ pre-US period $\left(0.2^{\star}\right.$ interstimulus interval) that were larger than $5 \%$ of full eyelid closure were considered significant and thus counted as a conditioned response (CR). Based on trial-by-trial analysis, the percentage of CR-positive trials from all valid trials (percentage CR) was calculated for each animal.

Open-field test. Anxiety and fear learning tests were done as described previously (Neufeld-Cohen et al., 2010). In this test, the mouse is faced with the natural conflict between the exploration of a novel environment and the evasiveness of a brightly lit area. The open-field test was performed in a $50 \times 50 \times 22 \mathrm{~cm}$ white box lit to 120 lux. The mice were placed in the box for $10 \mathrm{~min}$. Locomotion in the box was quantified using a video-tracking system (VideoMot2; TSE Systems; RRID:SCR_014334).

Fear conditioning. Fear conditioning was done using a computercontrolled system (TSE Systems) as described previously (Chen et al., 2006). Briefly, on day 1, mice were habituated for $5 \mathrm{~min}$ to a fear-condi- tioning chamber. On day 2, conditioning took place in 15 min training session, during which mice were exposed to 2 pairings of a tone [(CS: $30 \mathrm{~s}$, $3000 \mathrm{~Hz}$, pulsed $10 \mathrm{~Hz}, 80 \mathrm{db}(\mathrm{A})$ ] and a coterminating shock (US: 0.7 $\mathrm{mA}, 2 \mathrm{~s}$, constant current) with an intertrial interval (ITI) of $60 \mathrm{~s}$. The US was delivered through a metal grid floor. On day 3 , context-dependent memory and cued memory were tested by recording the percentage of time spent freezing.

Startle response. The startle response protocol was adapted from Neufeld-Cohen et al. (2010). Briefly, mice were placed in a small Plexiglas and wired mesh cage on top of a vibration-sensitive platform in a soundattenuated, ventilated chamber. A high-precision sensor integrated into the measuring platform detected movement. Two high-frequency loudspeakers inside the chamber produced all the audio stimuli. The acoustic startle response session began with 5 min acclimatization to white background noise $[65 \mathrm{db}(\mathrm{A})]$ maintained through the whole session. Thirtytwo startle stimuli [ $120 \mathrm{db}(\mathrm{A}), 40 \mathrm{~ms}$ duration with a randomly varying ITI of 12-30 s] were presented. Latency to peak startle amplitude was also measured.

\section{Statistical analyses}

Values are presented as mean \pm SEM. All analysis and data collection were automated and blinded as much as possible. For behavioral, transcriptional, and in situ data, mice with $Z$ scores higher than $|2|$ in at least half the measurement of a given test were excluded from that test. For all nonrepeated analysis, two-sided unpaired Student's $t$ test or nonparametric Mann-Whitney $U(\mathrm{MW}-\mathrm{U})$ tests were used to determine the level of significance according to the data distribution in the specific test. When normal sphericity could not be assumed, the recommended correction for unequal variance was performed. Repeated training sessions (EBC) were analyzed using repeated-measures ANOVA. Electrophysiology data were analyzed using the one-way ANOVA. For ANOVAs, Tukey's test was used as post hoc test. $N$ indicates the number of mice and $n$ indicates the number of recordings, cells, or slices used for the analysis. Data were considered significant if $p<0.05$. No statistical methods were used to predetermine sample sizes, but our sample sizes are similar to those reported previously (Giovannucci et al., 2017).

\section{Results}

\section{Mice show dense expression of $\mathrm{CRFR}_{1}$ in the cerebellar GrC layer}

To validate and evaluate the extent of $\mathrm{CRFR}_{1}$ and CRF expression in the cerebellum, we generated a reporter mouse line by crossbreeding $\mathrm{CRFR}_{1}{ }^{-\mathrm{GFP}}$ mice, CRF-Cre, and floxed-stop tdTomato to obtain GFP signal in $\mathrm{CRFR}_{1}$-expressing cells and tdTomato in CRF-expressing cells (Fig. 1a). To better visualize the layers of the cerebellar cortex, we also performed immunohistochemical staining for calbindin, a Purkinje cell marker (Batini, 1990) (Fig. 1b-f; $\mathrm{CRFR}_{1}{ }^{\mathrm{GFP}}$, green; CRF-tdTomato, red; Purkinje cells, cyan). Figure $1 b-f$, shows the dense population of $\mathrm{CRFR}_{1}$-expressing cells in the $\mathrm{GrC}$ layer, as expected. Importantly, tdTomato-expressing glomeruli were detected between the GrCs, indicating that mossy fibers expressing CRF indeed reach these cells (Fig. $1 g-i$ ). Movie 1 of cleared CRF-tdTomato mouse brain depicts fibers originating in CRF-positive neurons reaching the cerebellum (Movie 1, Fig. 1j). Both mossy fibers (originating mainly from the pontine nuclei) and climbing fibers (originating in the inferior olive) show marked expression of tdTomato (Fig. $1 j$, left and right).

\section{Establishing a mouse model depleted of $\mathrm{CRFR}_{1}$ specifically in $\mathrm{GrCs}$}

To study the role of $\mathrm{CRFR}_{1}$ in GrCs, we generated a conditional $\mathrm{CRFR}_{1}{ }^{\mathrm{KO}}$ mouse line depleted of $\mathrm{CRFR}_{1}$ specifically in GrCs using the Cre-lox system and the $\Delta \alpha 6$-Cre mouse line expressing Cre recombinase specifically in GrCs (see Materials and Methods). We first assessed the applicability of the $\Delta \alpha 6$-Cre mouse line for $\mathrm{GrCs}_{\mathrm{CRFR}}$ depletion (Figs. 2-1 and 2-2, available 
a

CRFR $_{1}$ - GFP $\quad x$ CRF - Cre $x$
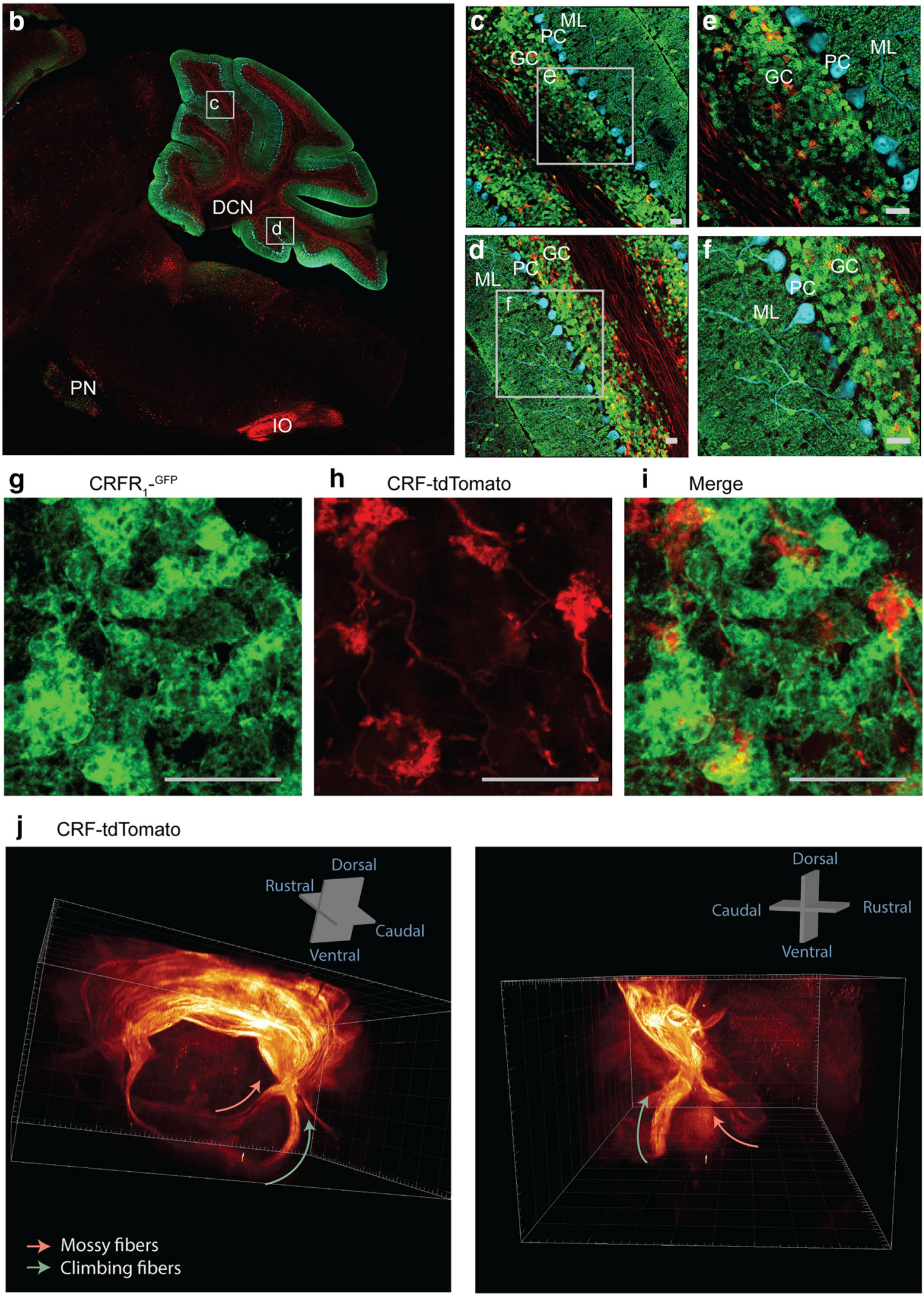

Figure 1. CRFR, is highly expressed in GrCs of mice. $\boldsymbol{a}$, Reporter mouse line expressing GFP under the CRFR, promoter and tdTomato in CRF expressing cells was generated by crossbreeding the $\mathrm{CRFR}_{1}{ }^{\text {GFP }}$ mouse line with CRF-Cre mouse line and mice conditionally expressing tdTomato. $\boldsymbol{b}-\boldsymbol{f}$, Sagittal cerebellar slice of the reporter line (b) with cortical magnifications (c-f) expressing GFP under the CRFR promoter and tdTomato in CRF-expressing neurons; Purkinje cells are stained with calbindin (cyan; scale bar, $25 \mu \mathrm{m}$ ). $\boldsymbol{g}$ - $\boldsymbol{i}$, Magnification of the $\mathrm{GrC}$ layer. $\boldsymbol{g}$, High magnification of GrCs clearly showing a dense population of GrCs expressing CRFR in the granular layer. $\boldsymbol{h}$, Glomeruli with tdTomato signal reaching the granular layer showing that mossy fibers expressing CRF reach the GrC layer. $\boldsymbol{i}$, Merged image of glomeruli expressing tdTomato (CRF; red) and GrCs expressing GFP (CRFR ; green). $\boldsymbol{j}$, Mossy and climbing fibers expressing tdTomato in (RF-positive cells in a cleared mouse brain. PN, Pontine nucleus; 10, inferior olive; ML, molecular layer; PC, Purkinje cell layer; GC, GrC layer. 


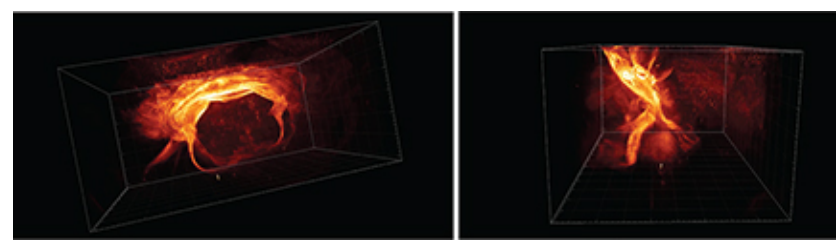

Movie 1. CRF-expressing cells give rise to mossy and climbing fibers. CRF-tdTomato mouse brain was cleared and imaged to depict fibers originating in CRF-positive neurons reaching the cerebellum. Mossy and climbing fibers show marked expression of tdTomato, indicating CRF input to the cerebellum via these two pathways.

at https://doi.org/10.1523/JNEUROSCI.3106-15.2018.f2-1 and https://doi.org/10.1523/JNEUROSCI.3106-15.2018.f2-2, respectively). Although previous work has reported no effect in $\Delta \alpha 6$-Cre on GABA equilibrium (Seja et al., 2012), we further examined levels of the GABA-A receptor $\alpha 6$ subunit (Gabra6) mRNA using qRT-PCR (Fig. 2-1a, available at https://doi.org/ 10.1523/JNEUROSCI.3106-15.2018.f2-1) and levels of protein using Western blot (Fig. 2-1b,c, available at https://doi.org/ 10.1523/JNEUROSCI.3106-15.2018.f2-1) in cerebella obtained from heterozygous Cre-expressing mice and WT mice. We did not detect any significant differences between the groups in Gabra6 levels (unpaired $t$ test, $t_{(10)}=1.18 p=0.26, N=7,5$; unpaired $t$ test, $t_{(6.77)}=1.89 p=0.1, N=7,6$; Figs. 2- $1 a$, and 2-1b,c, respectively, available at https://doi.org/10.1523/JNEUROSCI.3106-15.2018.f21). We further cross-bred $\Delta \alpha 6$-Cre mice with conditional tdTomatoexpressing mice (floxed-stop-tdTomato; see Materials and Methods) to evaluate Cre expression specificity (Fig. 2-1d,e, available at https://doi.org/10.1523/JNEUROSCI.3106-15.2018.f2-1). Indeed, tdTomato signal was strongly evident in the cerebellum and negligible in the rest of the CNS. To assess expected on-target and off-target depletion of $\mathrm{CRFR}_{1}$, we used a reporter mouse line generated by crossbreeding the $\Delta \alpha 6$-Cre with conditional tdTomato-expressing mice and the $\mathrm{CRFR}_{1}{ }^{\mathrm{GFP}}$ mouse expressing GFP in CRFR $_{1}$-expressing cells (Fig. 2-2a, available at https:// doi.org/10.1523/JNEUROSCI.3106-15.2018.f2-2). We then quantified colocalization between tdTomato-expressing cells and GFP-expressing cells in the GrCs layer and in extracerebellar structures (Fig. 2-2b-e, available at https://doi.org/10.1523/ JNEUROSCI.3106-15.2018.f2-2). As expected, CRFR $_{1}$ showed high colocalization with Cre-recombinase in the GrC layer, as indicated by GFP and tdTomato signal ( $94 \% \pm 1.3$ of GFP signal is coexpressed with tdTomato, $n=9, N=2$; Fig. 2-2b,c, available at https://doi.org/10.1523/JNEUROSCI.3106-15.2018.f2-2). Other brain regions, however, showed low to almost absent colocalization of GFP and tdTomato, which supports the validity of this model and insures minimal off-target deletion (mean percentage colocalization \pm SEM: cortex $=6 \pm 0.08 \%$, hippocampus $=$ $5.2 \pm 0.1 \%$, deep cerebellar nuclei $(\mathrm{DCN})=0 / 190$ cells, pontine $=27 \pm 2.4 \%$, thalamus $=2.3 \pm 0.08 \%, n=5-9$ slices, $N=$ 2; Fig. 2-2d,e, available at https://doi.org/10.1523/JNEUROSCI. 3106-15.2018.f2-2).

To generate a GrC-specific $\mathrm{CRFR}_{1}{ }^{\mathrm{cKO}}$ mouse line, $\Delta \alpha 6$-Cre mice were crossbred with mice with loxP flanking exon 2 of the $\mathrm{CRFR}_{1}$ gene (floxed-CRFR ; see Materials and Methods; Fig. $2 a$ ). $\mathrm{CRFR}_{1}$ depletion was assessed using $\mathrm{qRT}-\mathrm{PCR}$. CRFR $\mathrm{C}_{1}$ levels in the cerebella of cKO mice were reduced by $>90 \%$ compared with control mice (control dCT mean $=-0.3 \pm 0.14, \mathrm{CRFR}_{1}{ }^{\mathrm{cKO}} \mathrm{dCT}$ mean $=5.59 \pm 0.62,=\mathrm{MW}-\mathrm{U}=48, p=0.002, N=8$, 6; Fig. $2 b$ ). Importantly, other key regions did not show any significant reduction in $\mathrm{CRFR}_{1}$ levels ( $\mathrm{dCT}$ means $\pm \mathrm{SEM}$ : cortex control $=$ $4.3 \pm 0.2, \mathrm{CRFR}_{1}{ }^{\mathrm{cKO}}=4.1 \pm 0.2$, hippocampus control $=$ 5.3.7 $\pm 0.05, \mathrm{CRFR}_{1}{ }^{\mathrm{cKO}}=3.6 \pm 0.09$, pontine control $=0.6 \pm$ $0.2, \mathrm{CRFR}_{1}{ }^{\mathrm{cKO}}=0.9 \pm 0.3$, thalamus control $=4.7 \pm 0.1$, $\mathrm{CRFR}_{1}{ }^{\mathrm{cKO}}=4.5 \pm 0.2, N=6,6$; DCN control $=2.3 \pm 0.49$, $\mathrm{CRFR}_{1}{ }^{\mathrm{cKO}}=3.7 \pm 0.44,=N=3,5$; unpaired $t$ test, or MW-U $p=0.373-0.991$; Fig. $2 c$ ). We further examined gross morphology of the cerebellum and GrCs and found no differences in cerebellar weight (control mean weight $=0.0588 \pm 0.0007 \mathrm{mg}$, $\mathrm{CRFR}_{1}{ }^{\mathrm{cKO}}$ mean weight $=0.0572 \pm 0.0012 \mathrm{mg}$, unpaired $t$ test, $t_{(13)}=1.12, p=0.284, N=8$, 7; Fig. $2 d$ ) or cerebellar volume (control mean $=38.26 \pm 1 \mathrm{~mm}^{3}, \mathrm{CRFR}_{1}{ }^{\mathrm{cKO}}$ mean $=39.5 \pm 1.5$ $\mathrm{mm}^{3}$, unpaired $t$ test, $t_{(13)}=-1.13 p=0.277, n=7,8$; Fig. $2 e$ ). Golgi-stained GrCs did not significantly differ between control and $\mathrm{CRFR}_{1}{ }^{\mathrm{cKO}}$ in soma diameter (control mean $=7.79 \pm 0.18$ $\mu \mathrm{m}, \mathrm{CRFR}_{1}{ }^{\mathrm{cKO}}$ mean $=7.85 \pm 0.16 \mu \mathrm{m}$, unpaired $t$ test, $t_{(92)}=$ $0.23, p=0.82, n=43,51, N=2$; Fig. $2 f$ ) or number of dendrites (control mean $=3.6 \pm 0.4, \mathrm{CRFR}_{1}{ }^{\mathrm{cKO}}$ mean $=3.2 \pm 0.1$, unpaired $t$ test, $t_{(4)}=-0.84, p=0.45, n=6,10$ cells; $N=3,3$ ).

\section{Increased intrinsic excitability in GrCs depleted of $\mathrm{CRFR}_{1}$}

We first set out to test the electrophysiological properties of the GrCs of $\mathrm{CRFR}_{1}{ }^{\mathrm{cKO}}$. Similar to previous reports on rodent cerebella (D’Angelo et al., 1995, 1999; Rossi et al., 1998; Armano et al., 2000; Prestori et al., 2008), the present recordings for both control and Cre GrCs were characterized by fast repetitive spike discharge (Fig. 3a). However, $\mathrm{CRFR}_{1}{ }^{\mathrm{cKO}} \mathrm{GrCs}$ showed a set of differences in spikes and firing pattern compared with GrCs of controls. $\mathrm{CRFR}_{1}{ }^{\mathrm{cKO}} \mathrm{GrCs}$ showed a higher average discharge frequency at low current injection (24 pA: control, $9.6 \pm 3.6 \mathrm{~Hz}, n=$

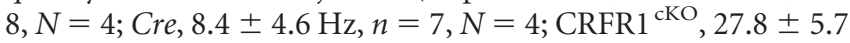
$\mathrm{Hz}, n=5, N=3$; one-way ANOVA $F_{(2,17)}=5.6, p=0.013$; Tukey's post hoc pairwise comparisons, control flox vs control Cre,$p=0.98$; control flox vs CRFR $1^{\mathrm{cKO}}, p=0.024$; control Cre vs CRFR $\left.1^{\mathrm{cKO}}, p=0.02\right)$, but showed a lower average discharge frequency at higher current injections ( $44 \mathrm{pA}$ : control, $32.0 \pm 7.0$ $\mathrm{Hz}, n=8, N=4$; Cre, $45.3 \pm 12.7 \mathrm{~Hz}, n=7, N=4$; CRFR $1^{\mathrm{cKO}}$, $16.7 \pm 8.7 \mathrm{~Hz}, n=5, N=3$; One-way ANOVA $F_{(2,17)}=4.6, p=$ 0.025 control flox vs control Cre, $p=0.35$; Tukey's post hoc pairwise comparisons, control flox vs CRFR $1^{\text {cKO }}, p=0.047$; control Cre vs CRFR $\left.1^{\text {cKO }}, p=0.019\right)$. This generated a bell-shaped profile in the frequency-intensity plot (Fig. $3 b$ ), but because the reduced discharge frequency at the higher current injections only occurred after initial hyperbursting, the ultimate reduced average discharge rate may reflect some type of depolarization block after an initial hyperexcitation. The $\mathrm{CRFR}_{1}{ }^{\mathrm{cKO}} \mathrm{GrCs}$ spikes showed marked adaptation, a high threshold (44 pA, one-way ANOVA, $F_{(2,17)}=16.0, p=0.000125$; Tukey's post hoc pairwise comparisons: control flox vs control Cre, $p=0.31$; control flox vs CRFR $1^{\text {cKO }}, p=0.0013$; control Cre vs CRFR $\left.1^{\text {cKO }}, p=0.00015\right)$, small AHP (44 pA, one-way ANOVA, $F_{(2,17)}=10.8, p=0.00095$; Tukey's post hoc pairwise comparisons: control flox vs control Cre, $p=0.73$; control flox vs CRFR $1^{\text {cKO }}, p=0.0037$; control Cre vs CRFR $1^{\text {cKO }}, p=0.0011$ ) and smaller overshoot (32 pA, oneway ANOVA, $F_{(2,17)}=4.6, p=0.025$; Tukey's post hoc pairwise comparisons: control flox vs control Cre, $p=0.9$; control flox vs CRFR $1^{\mathrm{cKO}}, p=0.052$; control Cre vs CRFR $\left.1^{\mathrm{cKO}}, p=0.029\right)$ compared with the 2 control groups (control flox $n=8, N=4$; control Cre $n=7, N=4$; CRFR ${ }^{\text {cKO }} n=5, N=3$; Fig. $\left.3 a, c\right)$. Altered intrinsic excitability in $\mathrm{CRFR}_{1}{ }^{\mathrm{cKO}}$ mice did not depend on series resistance $\left(R_{\mathrm{s}}\right)$, membrane capacitance $\left(C_{\mathrm{m}}\right)$, membrane resistance $\left(R_{\mathrm{m}}\right)$, or resting membrane potential, which were all similar regardless of the recorded cell group (Table 1). 
a

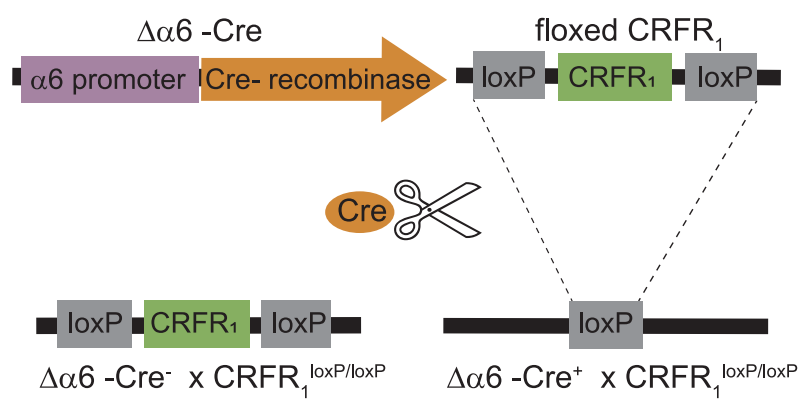

b

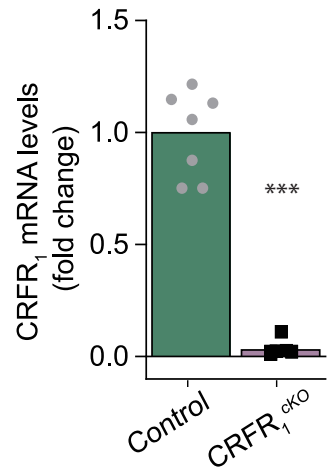

C

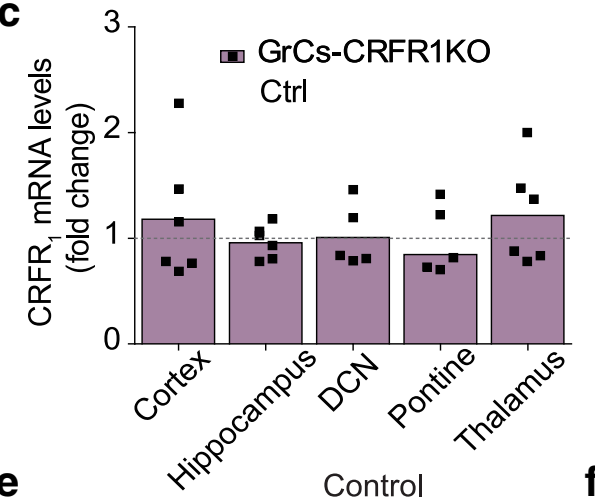

d

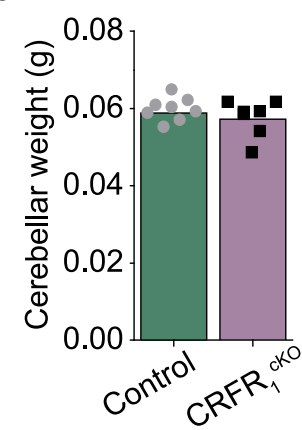

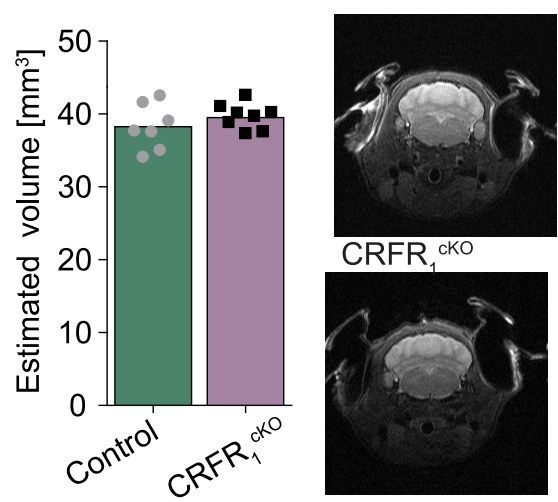

f

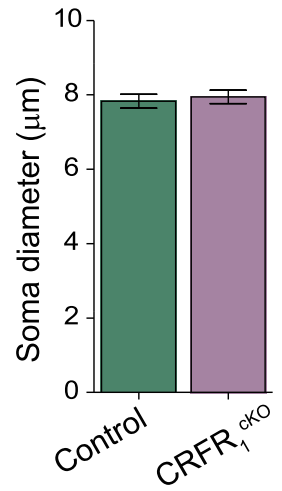

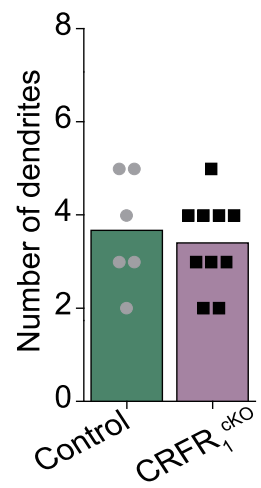

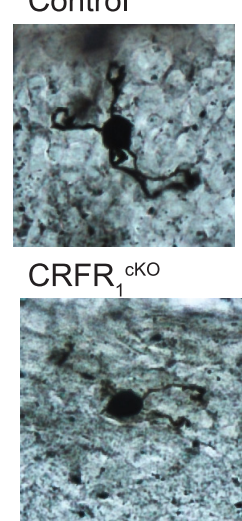

Figure 2. Establishment of a mouse line depleted of CRFR, specifically in cerebellar GrCs. The $\alpha 6$ subunit levels in $\Delta \alpha 6$-Cre line cerebella and the Cre line granular specificity are presented in Figure 2-1 (available at https://doi.org/10.1523/JNEUROSCI.3106-15.2018.f2-1). $\boldsymbol{a}$, Schematic representation of cell-specific deletion of CRFR ${ }_{1}$ using the Cre-lox system. $\boldsymbol{b}$, CRFR, mRNA is reduced

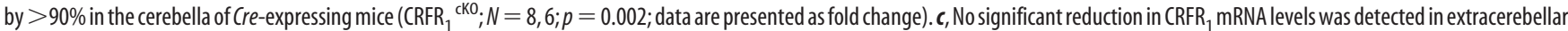
regions in $\mathrm{CRFR}_{1}{ }^{\mathrm{CKO}}$ (mRNA levels presented are normalized to control levels, represented as dashed gray line, $N=3-6$ per group, $p=0.373-0.991$; data are presented as fold change). Image analysis of colocalization levels of Cre activity in the $\Delta \alpha 6$-Cre line and (RFR ${ }_{1}$ expression are presented in Figure 2-2 (available at https://doi.org/10.1523/JNEUROSCI.3106-15.2018.f2-2). $\boldsymbol{d}-\boldsymbol{f}$, Cerebellar structural properties. No differences in cerebellar weight $(N=8,7 ; p=0.284 ; \boldsymbol{d})$ or cerebellar volume (quantification and representative image of MRI scan, $N=7,8 ; p=0.277$; e) were detected. $\boldsymbol{f}$, No differences in $\operatorname{GrC}$ soma size or number of dendrites were detected in $\mathrm{CRFR}_{1}{ }^{{ }^{\mathrm{K} O} 0}$ compared with control mice (diameter: $n=43,51$ cells, $N=2, p=0.82 ;$ dendrites $N=3$, $3 ; p=0.45)$. Data are represented as mean \pm SEM. ${ }^{* * *} p<0.005$.

The similarity of passive parameters (especially $C_{\mathrm{m}}$ ) is consistent with the normal soma diameter and homogenous shape reported in Figure $2 f$.

\section{GrCs depleted of $\mathrm{CRFR}_{1}$ show altered long-term synaptic plasticity}

The hyperexcitability in the GrCs in $\mathrm{CRFR}_{1}{ }^{\mathrm{cKO}}$ mice might have induced some secondary changes in plasticity at the mossy fiber to GrC synapse. Normally, high-frequency stimulation induces LTP at this synapse (Andreescu et al., 2011; Prestori et al., 2013). Indeed, in both control and Cre GrCs, robust action potential discharge was generated by delivering TBS in current-clamp recordings (Fig. 4c). Conversely, in $\mathrm{CRFR}_{1}{ }^{\mathrm{cKO}}$ mice, although TBS caused a strong depolarization, no spikes could be elicited in response to TBS (Fig. $4 c-e$ ). After TBS, the EPSC in WT mice increased, following a similar time course in control and Cre strains, and remained potentiated throughout the recordings (at least 20 min after TBS; average time courses are shown in Fig. $4 a, b)$. At $20 \mathrm{~min}$ after TBS, the EPSC increase was $32.7 \pm 5.5 \%$ in control $(n=5, N=4)$ and $32.3 \pm 3.9 \%$ in Cre mice $(n=5, N=$ 4). However, the CRFR $1{ }^{\mathrm{cKO}}$ group showed LTD rather than LTP following the same induction protocol $(-38.4 \pm 10.3 ; n=5, N=$ $4 ; F_{(2,12)}=21.3, p=0.00017$; Tukey's post hoc pairwise comparisons: control flox vs control Cre, $p=0.64$; control flox vs CRFR $1^{\mathrm{cKO}}, p=0.00078$; control Cre vs CRFR $1^{\mathrm{cKO}}, p=0.00036$; Fig. $4 b)$. Note the absence of spike generation in the CRFR $1^{\text {cKO }}$ $\mathrm{GrC}$ (despite a robust depolarization) compared with the intense burst discharge of the control flox and control Cre GrCs (one- 
a
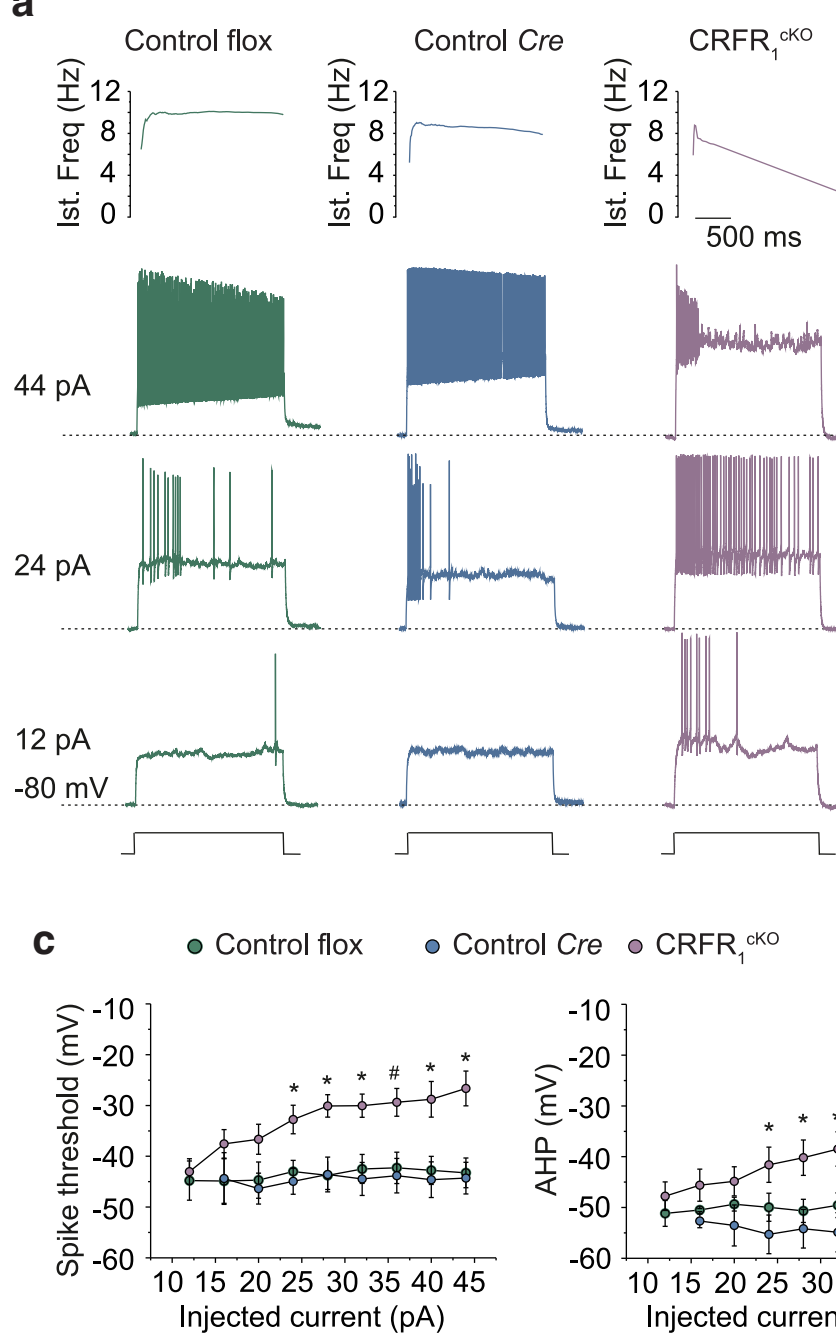
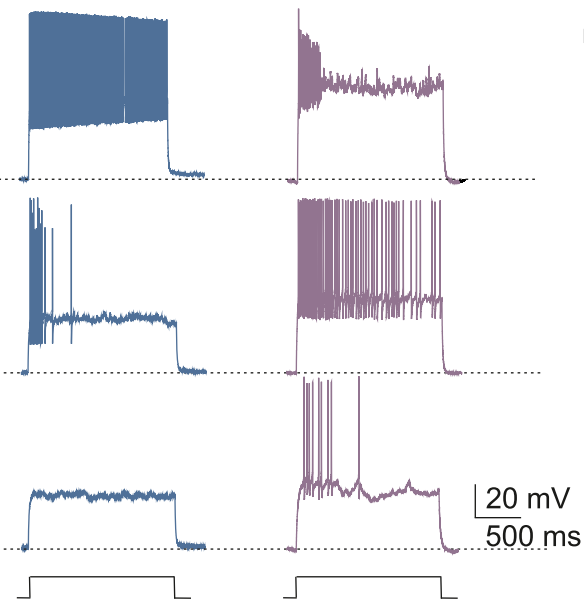

$500 \mathrm{~ms}$
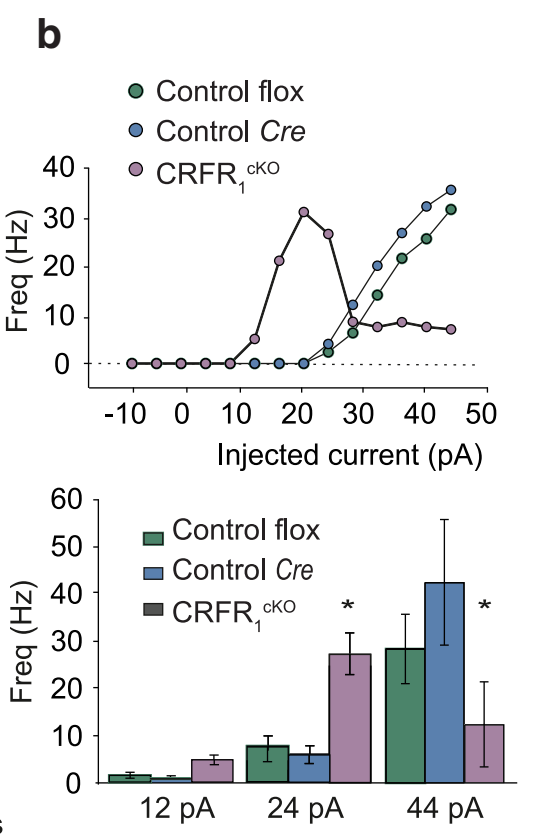

Figure 3. $\quad \mathrm{CRFR}_{1}{ }^{\mathrm{ck} 0} \mathrm{GrCs}$ showing different electro-responsiveness from control mice. $a$, Examples of voltage responses elicited from - $80 \mathrm{mV}$ using step current injections in control for the floxed alleles (control flox), control for the $\Delta \alpha 6$ - Cre (Control (re), and CRFR1 ${ }^{\text {cko }}$ mice. Instantaneous spike frequency is represented on top, showing rapid increase and marked adaptation in (RFR1 ${ }^{\text {cKO }}$ mice. $\boldsymbol{b}$, Frequency/intensity plots for the same cells in $\boldsymbol{a}$. Note that the CRFR $1{ }^{\mathrm{cK} 0} \mathrm{GrC}$ shows higher discharge frequency at low current injection and lower discharge frequency at high current injection compared with control and Cre cells, generating a characteristic bell-shaped response profile. The histograms at the bottom show average discharge frequency values at different current injection for all recorded cells (control flox $n=8, N=4$; control Cren $=7, N=4$; CRFR1 ${ }^{\mathrm{k} 0} n=5, N=3$ ). c, Spike threshold, AHP, and spike peak in the different groups of GrC control flox $n=8, N=4$; control

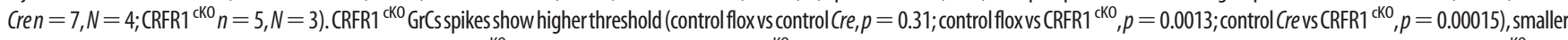
AHP (control flox vs control Cre, $p=0.73$; control flox vs CRFR1 ${ }^{\mathrm{CKO}}, p=0.0037$; control Cre vs CRFR1 ${ }^{\mathrm{cKO}}, p=0.0011$ ), and smaller overshoot (control flox vs control Cre, $p=0.9$; control flox vs CRFR1 ${ }^{\mathrm{cKO}}, p=$ 0.052 ; control Cre vs CRFR $1{ }^{\mathrm{ck} 0}, p=0.029$ ) compared with the 2 control groups. Data are represented as mean \pm SEM. \#p $<0.05,{ }^{*} p<0.005$ for one-way. Ind, Induction.

way ANOVA, $F_{(2,12)}=8.7, p=0.0054$; Tukey's post hoc pairwise comparisons: control flox vs control Cre, $p=0.64$; control flox vs CRFR $1^{\mathrm{cKO}}, p=0.023$; control Cre vs CRFR $1^{\mathrm{cKO}}, p=0.0065$; control flox $n=5, N=4$; control Cre $n=5, N=4$; CRFR1 ${ }^{\text {cKO }}$ $n=5, N=4$; Fig. $4 c$ ). Because Cre mice presented similar characteristics to floxed control mice and no effect of the Cre knock-in was detected, floxed mice were used as controls for the rest of the experiments.

Cerebellar gene expression is altered by $\mathrm{GrC} \mathrm{CRFR}_{1}$ depletion $\mathrm{CRFR}_{1}$ is a G-protein-coupled receptor and thus is expected to have an effect on transcription. We hypothesized that the expression of genes related to its function will be altered. To test this, we collected cerebella obtained from $\mathrm{CRFR}_{1}{ }^{\mathrm{CKO}}$ and control mice, extracted mRNA, and sequenced them using Illumina sequencing technology. Analysis of the mRNA sequencing revealed differential expression in a large variety of genes ( 563 genes, adjusted $p<0.05$ ); however, only 10 genes showed an upregulation or downregulation larger than 0.4-fold change (Log2; Fig. 5a). Atp2 b4, a gene coding for the calcium transporting plasma membrane ATPase 4 (PMCA4), was shown previously to be correlated with $\mathrm{CRFR}_{1}$ levels in the cerebellar cortex of genetically distonic rats (Xiao et al., 2007). We thus chose to further validate its downregulation in the cerebella of $\mathrm{CRFR}_{1}{ }^{\mathrm{cKO}}$ mice. Indeed, Atp 264 mRNA levels were downregulated by $50 \%$ in $\mathrm{CRFR}_{1}{ }^{\text {cKO }}$ mice compared with controls $(\mathrm{dCT}$ control $=4.3 \pm 0.1$, dCT $\mathrm{CRFR}_{1}{ }^{\mathrm{cKO}}=5.3 \pm 0.1, t_{(10)}=6.416, p<0.001, N=7,5$; Fig. $5 b$; in an additional cohort, downregulation was to a similar extent, $t_{(12)}=2.386, p=0.034, N=7,7$; data not presented). Further analysis of PMCA4 levels revealed a $40 \%$ downregulation of the calcium transporter in $\mathrm{CRFR}_{1}{ }^{\mathrm{CKO}}$ at the protein level (relative intensity control $=1.08 \pm 0.08, \mathrm{CRFR}_{1}{ }^{\mathrm{cKO}}=0.68 \pm 0.11, t_{(11)}=$ 2.911, $p=0.014, N=7,6$; Fig. $5 c$ ). Interestingly, and consistent with PMCA4 downregulation, analysis of all significantly down- 

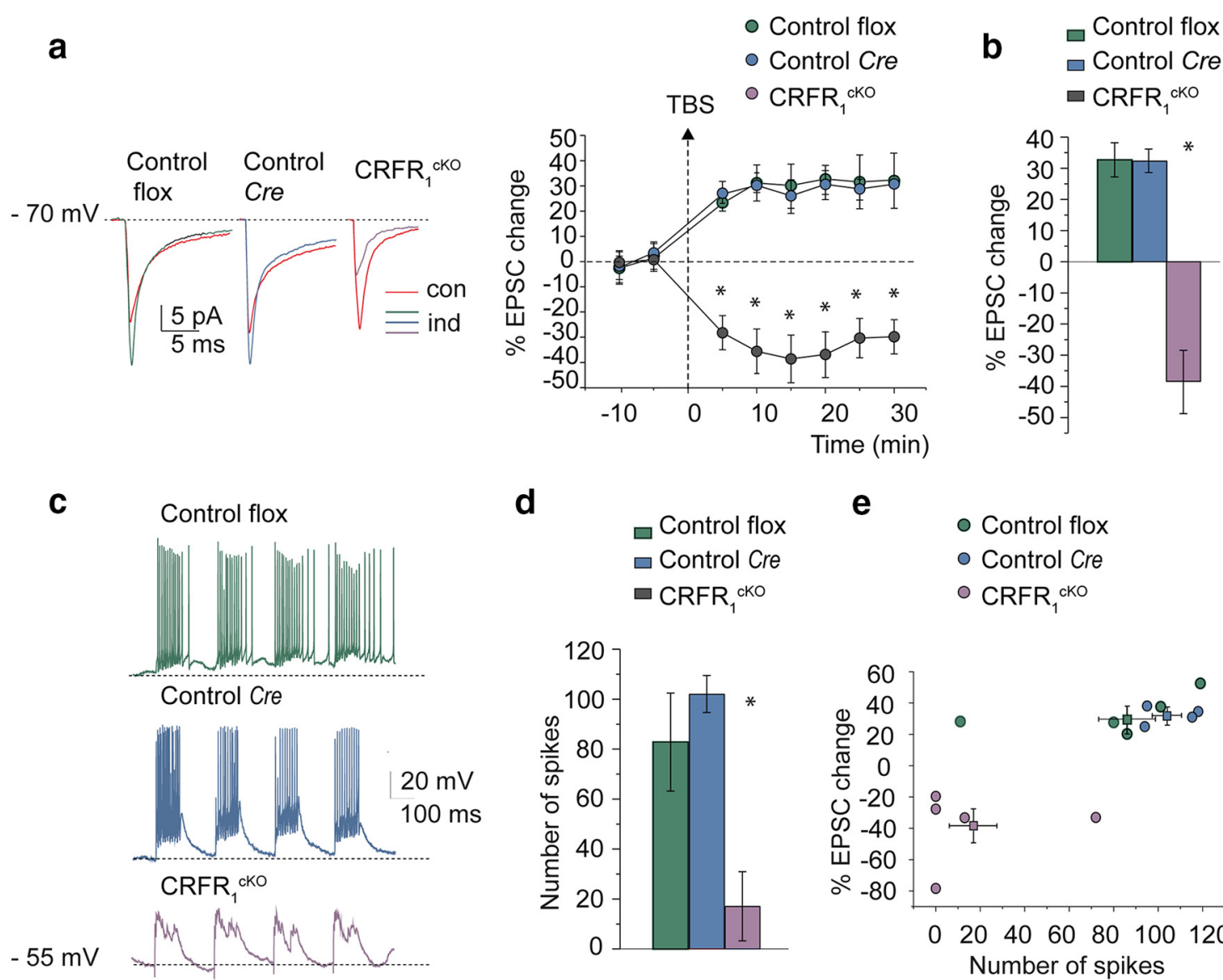

d
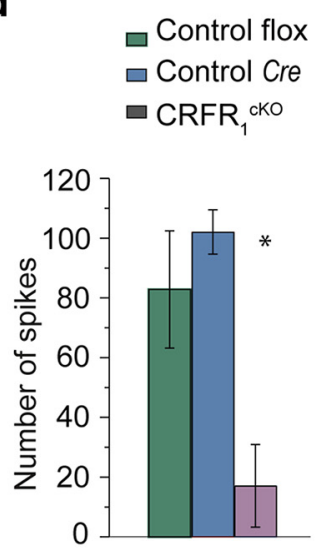

e

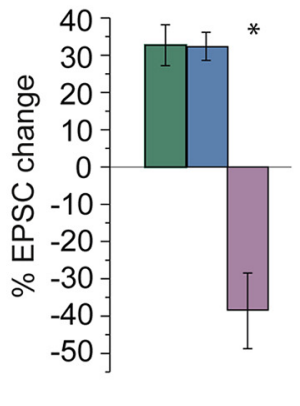

O Control flox
- Control Cre
O CRFR cko

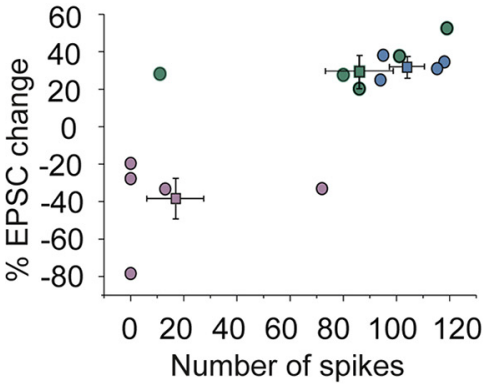

Figure 4. Long-term changes in mossy fiber- GrC EPSCS are markedly different in CRFR ${ }^{\mathrm{CK} 0}$ and control mice. $a$, Average EPSCS (100 tracings) obtained during control and 20 min after TBS application are shown superimposed in control flox, control Cre, and CRFR1 ${ }^{\mathrm{KK} 0} \mathrm{GrCS}$. After TBS, EPSCs increased in flox and Cre mice but decreased in the CRFR ${ }^{\mathrm{ck0}} \mathrm{GrCS}$. The plot shows the average time course of EPSC amplitude changes (control flox $n=5, N=4$; control Cren $=5, N=4 ;$;RFR1 ${ }^{\mathrm{CK} 0} n=5, N=4$ ). $\boldsymbol{b}$, Histogram showing ensemble EPSC amplitude changes at 20 min after TBS compared with baseline (control flox vs control Cre, $p=0.64$; control flox vs CRFR1 ${ }^{\mathrm{CK} 0}, p=0.00078$; control Cre vs CRFR1 ${ }^{\mathrm{ck} 0}, p=0.00036$ ). $c$, Examples of GrC responses elicited by TBS. Note the absence of spike generation in the CRFR1 ${ }^{\mathrm{KK} 0} \mathrm{GrC}$ (despite a robust depolarization) compared with the intense burst discharge of the control flox and control Cre GrCs (control flox vs control Cre, $p=0.64$; control flox vs CRFR1 ${ }^{\mathrm{kK} 0}, p=0.023$; control Cre vs CRFR1 ${ }^{\mathrm{CK} 0}, p=0.0065$ ). $\boldsymbol{d}$, Histogram showing ensemble number of spikes generated during TBS (control flox $n=5, N=4 ;$ control

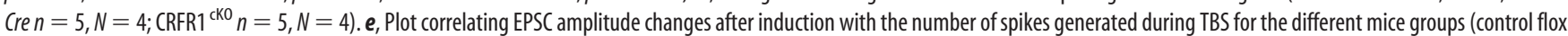
$n=5, N=4$; control Cre $n=5, N=4$; (RFR1 ${ }^{\mathrm{CK} 0} n=5, N=4$; individual data points and mean \pm SEM are shown for each group). Data are represented as mean \pm SEM. ${ }^{*} p<0.005$.

regulated or upregulated genes using IPA revealed that the calcium-signaling pathway was the most altered pathway in the cerebella of $\mathrm{CRFR}_{1}{ }^{\text {cKO }}$ mice $\left(p=1.26 \mathrm{e}^{-04}\right)$.

\section{$\mathrm{CRFR}_{1}{ }^{\mathrm{cKO}}$ mice show accelerated learning in the EBC procedure}

Because the cerebellum, including its granular layer, is known to play a role in procedural learning (Gao et al., 2012; Galliano et al., 2013; Giovannucci et al., 2017), we next subjected the $\mathrm{CRFR}_{1}{ }^{\mathrm{cKO}}$ mice to a cerebellar-specific conditioning procedure, delay EBC. The mossy fiber to GrC pathway is thought to convey the CS signal to the cerebellum (Yeo and Hesslow, 1998; De Zeeuw and Yeo, 2005). We used the MDMT (Koekkoek et al., 2002) for EB recordings, which allows a good measure of the mouse eyelid closure during CS presentation relative to eyelid closure during US presentation by measuring the distance between a magnet placed on the eyelid and a detector (Fig. 6a). EBC was performed by pairing a neutral CS, an LED light presented for a period of 330 $\mathrm{ms}$, which coterminated for $30 \mathrm{~ms}$ with a US, a mild air puff to the cornea (Fig. 6a,b). Mice typically learn to close their eye in response to the CS in a timely manner, that is, close to US presentation, forming the CR. Figure 5, $c$ and $d$, present a heatmap of group averages of eyelid closure in individual trials (1000 trials in total; control: Fig. $6 c, \mathrm{CRFR}_{1}{ }^{\mathrm{cKO}}$ : Fig. $6 d$ ). Figure $4, e$ and $f$, presents the group average of eyelid traces of each of 10 training sessions for control (Fig. 6e) and $\mathrm{CRFR}_{1}{ }^{\mathrm{cKO}}$ (Fig. 6f) mice. As evident from Figure $6, c-f$, both $\mathrm{CRFR}_{1}{ }^{\mathrm{cKO}}$ and control mice showed a marked increase in eyelid closure before US presentation (Fig. $6 c-f$ ). Quantitative assessment of the percentage of CRs (calculated by assessing the number of CRs out of valid trials; see Materials and Methods) showed that both groups had learned the EBC procedure (repeated-measures ANOVA, main effect for session, $F_{(3.227,45.176)}=39.722, p<0.001$; Fig. $6 g$ ). However, $\mathrm{CRFR}_{1}{ }^{\mathrm{cKO}}$ mice showed a significantly higher percentage of CRs during EBC training (repeated-measures ANOVA, main effect for group, $F_{(1,13)}=13.561, p=0.002, N=6,10$; Fig. $6 g$ ). Importantly, the peaks of the CRs were close to the US presentation, indicating the well timed character of the responses (for the response time probability of the CRs in session 10, see Fig. 6-1, available at https:// doi.org/10.1523/JNEUROSCI.3106-15.2018.f6-1). When trained on a shorter CS-US interval $(250 \mathrm{~ms}), \mathrm{CRFR}_{1}{ }^{\mathrm{cKO}}$ mice showed faster learning of the response, but both groups reached a similar CR percentage after 10 conditioning sessions (control = $46 \pm 15 \%$, $\mathrm{CRFR}_{1}{ }^{\mathrm{cKO}}=49 \pm 22 \%$, repeated-measures ANOVA, main effect for group, $F_{(1,12)}=5.56, p=0.036, N=9$, 5; Fig. 6-2, available 
a
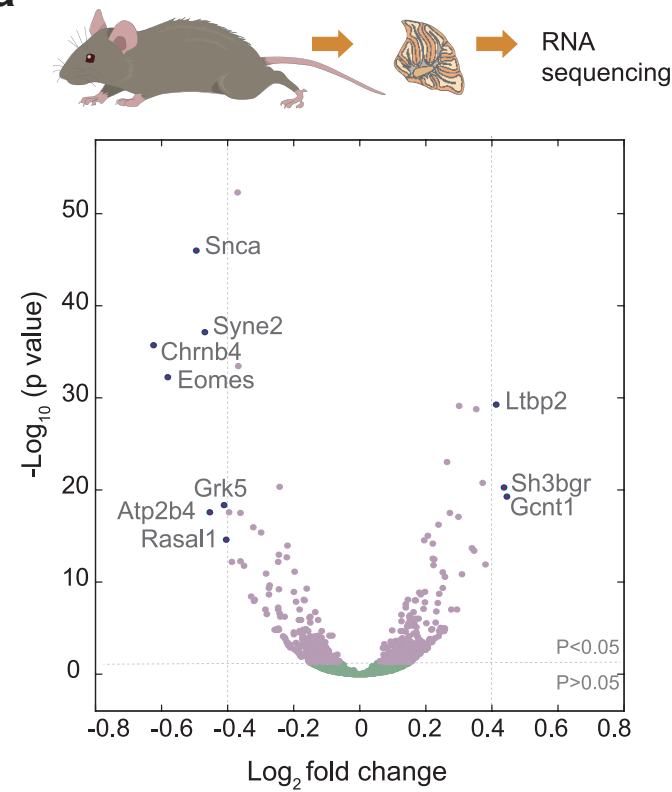

b

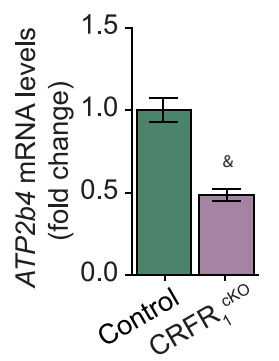

C
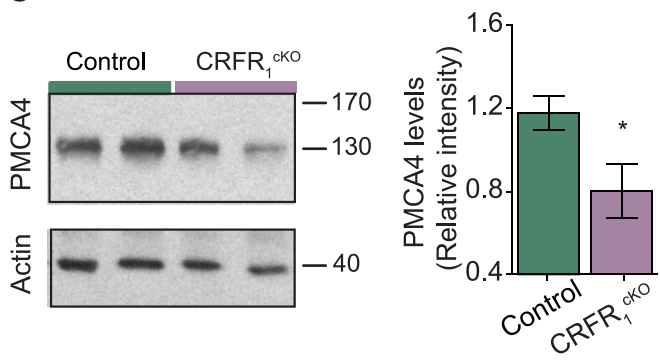

Figure 5. Whole cerebellum mRNA sequencing reveals significant differences in transcriptome of control and CRFR ${ }_{1}{ }^{\mathrm{KK} 0}$ mice. $\boldsymbol{a}, \log 2 \mathrm{mRNA}$ analysis of CRFR ${ }_{1}{ }^{\mathrm{K} 0}$ and control cerebella mice revealed 563 significantly upregulated or downregulated genes (light purple dots; $N=6,6$ ). Ten genes showed log2 change larger than \pm 0.4 (fold change $>30 \%$, dark purple dots; 3 genes upregulated and 7 downregulated). $\boldsymbol{b}$, Real-time qRT-PCR analysis was used to validate the downregulation of $A t p 2 b 4$ mRNA levels in CRFR $_{1}{ }^{{ }^{K 0} 0}$ mice compared with controls $(N=7,5 ; p<0.001)$. c, Quantification by Western blot (WB) of PMCA4, the protein coded by the Atp264 gene, validates its translation downregulation in cerebella of $\mathrm{CRFR}_{1}{ }^{\mathrm{CKO}}(N=7,6 ; p=0.014)$. Data are represented as mean \pm SEM. ${ }^{*} p<0.05,{ }^{\&} p<0.001$.

at https://doi.org/10.1523/JNEUROSCI.3106-15.2018.f6-2). Together, these results further support the role of GrCs in learning and suggest a significant role for $\mathrm{CRFR}_{1}$ specifically in the learning properties of GrCs.

\section{Motor performance and fear- and anxiety-related behaviors are intact in $\mathrm{CRFR}_{1}{ }^{\mathrm{cKO}}$ mice}

Mice with $\mathrm{GrCs}$ depleted of $\mathrm{CRFR}_{1}$ were tested for locomotion under baseline conditions using the inframot and for locomotion under challenging conditions using the rotarod and the treadmill. $\mathrm{CRFR}_{1}{ }^{\mathrm{cKO}}$ mice did not differ from their littermates in home cage locomotion during light or dark phases (measured in arbitrary units, AU, control dark $=3870 \pm 443 \mathrm{AU}$, light $=1266 \pm 932$ $\mathrm{AU}$, light $=867 \pm 250 \mathrm{AU}$, dark unpaired $t$ test, $t_{(11)}=1.114, p=$ 0.287 , light unpaired $t$ test, $t_{(7.128)}=-0.539 p=0.607, N=7,6$; Fig. $7 a, b)$. For the rotarod test, $\mathrm{CRFR}_{1}{ }^{\mathrm{cKO}}$ and control mice were subjected to 4 consecutive trials on a rod accelerating at $10 \mathrm{rpm} / \mathrm{min}$ or to 4 trials of $20 \mathrm{rpm} / \mathrm{min}$. The latencies to fall off the rod were summated for each mouse and averaged for each group. $\mathrm{CRFR}_{1}{ }^{\mathrm{cKO}}$ performance on the rotarod was indistinguishable from that of control mice (at $10 \mathrm{rpm}$, control $=231 \pm 27 \mathrm{~s}$, $\mathrm{CRFR}_{1}{ }^{\mathrm{cKO}}=222 \pm 19 \mathrm{~s}, \mathrm{MW}-\mathrm{U}=114, p=0.653, N=12,21$; at $20 \mathrm{rpm}$, control $=167 \pm 40 \mathrm{~s}, \mathrm{CRFR}_{1}{ }^{\mathrm{cKO}}=144 \pm 56 \mathrm{~s},=0.171$, $\mathrm{MW}-\mathrm{U}=38, N=13$, 9; Fig. $7 c$ ). To assess the potential differences in stress-induced motor performance, we used a treadmill apparatus that delivers a mild shock each time the mouse fails to run and falls on the grid (see Materials and Methods). On day 1 , the mice were familiarized with the apparatus, including the shock-delivering grid, and the mice had to learn that they had to run continuously to avoid the shocker. On the following day, mice were returned to the active treadmill and the number of falls on the grid was used to assess motor adequacy of the mice (Fig. $7 d) . \mathrm{CRFR}_{1}{ }^{\mathrm{cKO}}$ did not differ from their control counterparts in the performance on the treadmill (control $=38 \pm 5, \mathrm{CRFR}_{1}{ }^{{ }^{\mathrm{KOO}}=}$
$36 \pm 7$, unpaired $t$ test, $t_{(20)}=0.193 p=0.849, N=12,10$; Fig. $7 e$ ). Therefore, we can conclude that $\mathrm{CRFR}_{1}$ in $\mathrm{GrCs}$ probably does not play a critical role in motor performance under either basal or stressful conditions.

Because CRFR ${ }_{1}$ has been shown repeatedly to be involved in fear- and anxiety-related behaviors (Sztainberg and Chen, 2012; Henckens et al., 2016), we tested whether these were altered in $\mathrm{CRFR}_{1}{ }^{\mathrm{cKO}}$ mice. No differences in acoustic startle response were detected between the groups (control $=29 \pm 5 \mathrm{AU}, \mathrm{CRFR}_{1}{ }^{\mathrm{cKO}}=$ $39 \pm 6 \mathrm{AU}$, unpaired $t$ test, $t_{(26)}=-1.198, p=0.242, N=13,15$; Fig. $7 f)$. CRFR ${ }_{1}{ }^{c K O}$ mice tested in the open-field test did not show any marked differences from their control counterparts in time spent in the center (control $=90 \pm 27 \mathrm{~s}, \mathrm{CRFR}_{1}{ }^{\mathrm{cKO}}=41 \pm 6 \mathrm{~s}$, unpaired $t$ test, $\left.t_{(26)}=1.74, p=0.09\right)$, distance moved in the center $\left(\right.$ control $=922 \pm 151 \mathrm{~cm}, \mathrm{CRFR}_{1}{ }^{\mathrm{cKO}}=604 \pm 97 \mathrm{~cm}$, unpaired $t$ test, $t_{(26)}=1.77, p=0.9$ ) or number of visits to the center of the arena (control $=44 \pm 7$ visits, $\mathrm{CRFR}_{1}{ }^{\mathrm{cKO}}=30 \pm 4$ visits, unpaired $t$ test, $t_{(26)}=1.67, p=0.11, N=14$, 14; Fig. $7 g$ ). Likewise, $\mathrm{CRFR}_{1}{ }^{\mathrm{cKO}}$ mice exposed to a fear-conditioning procedure did not differ from control littermates in freezing duration during either cue or context presentation (context: control = $0.73 \pm 0.1, \mathrm{CRFR}_{1}{ }^{\mathrm{cKO}}=0.63 \pm 0.06$, unpaired $t$ test, $t_{(10)}=1.121$ $p=0.289, N=6,6$; cue: control $=0.79 \pm 0.08, \mathrm{CRFR}_{1}{ }^{\mathrm{cKO}}=$ $0.66 \pm 0.08$, unpaired $t$ test, $t_{(8)}=1.032 p=0.332, N=6$, 4; Fig. $7 h)$. These results show that $\mathrm{CRFR}_{1}{ }^{\mathrm{cKO}}$ mice do not have altered emotional valence and exclude the involvement of GrCs-CRFR in "emotionally susceptible" behaviors.

To conclude, $\mathrm{CRFR}_{1}$ depletion in the GrCs results in increased excitability of GrCs, a significantly altered cerebellar transcriptome including lowered expression of proteins involved in the calcium-signaling pathway and accelerated cerebellar learning in the EBC procedure. Together, these results suggest a significant role for $\mathrm{CRFR}_{1}$ in tempering GrCs' learning capacity. 


\section{a}

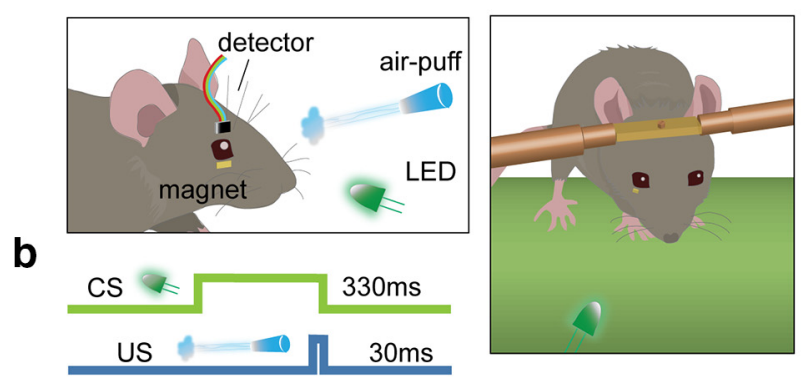

e

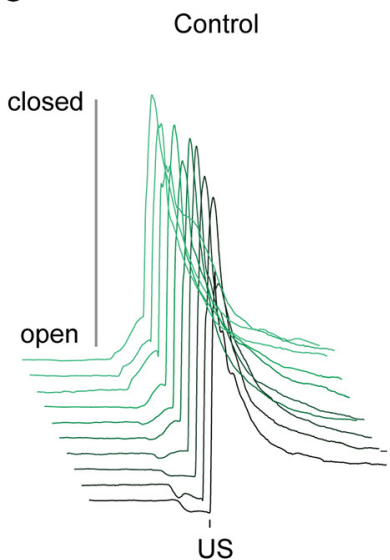

\section{f}

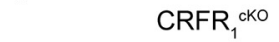

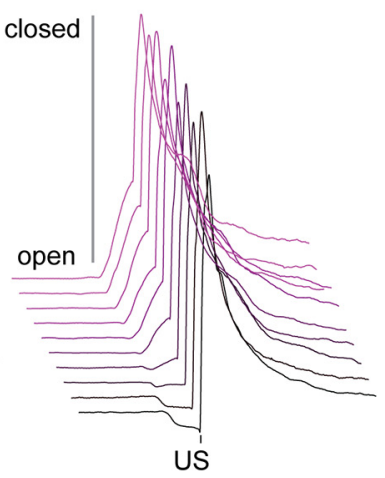

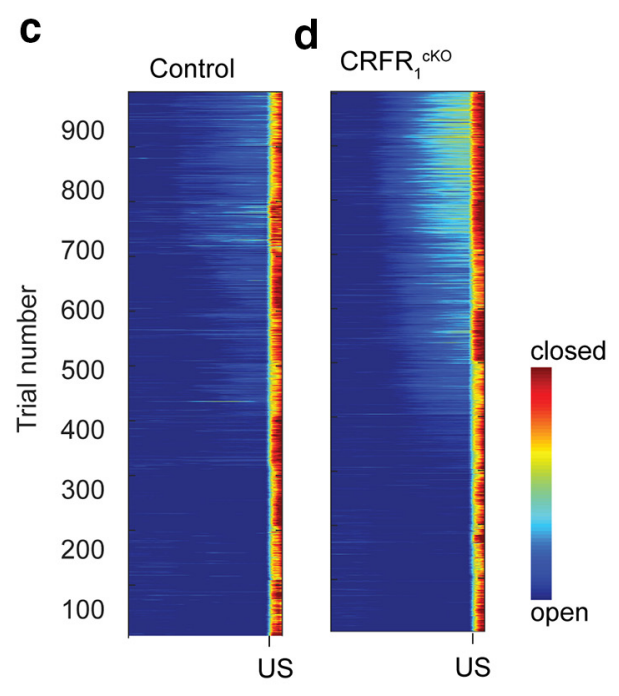

g

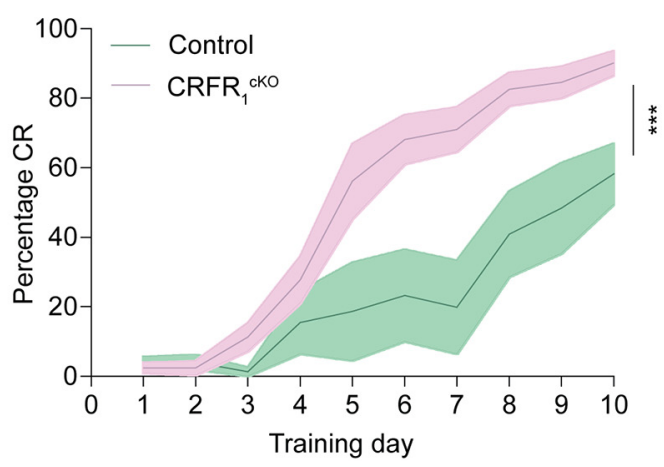

Figure 6. $\quad \mathrm{CRFR}_{1}{ }^{\mathrm{CK} 0}$ mice show enhanced learning in the EBC procedure compared with control mice. $\boldsymbol{a}$, Schematic illustration of EBC using the MDMT. $\boldsymbol{b}, 0$ ver the course of EBC, a $330 \mathrm{~ms}$ CS ( $\mathrm{green}$ line) was paired with a co-terminating $30 \mathrm{~ms}$ US (blue line). $\boldsymbol{c}, \boldsymbol{d}$, Heatmap of group averages of trial-by-trial eyelid closure over the entire course of conditioning for controls (c) and (RFR ${ }_{1}{ }^{\mathrm{K} O}$ mice

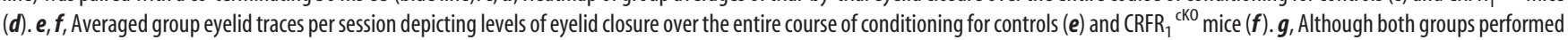

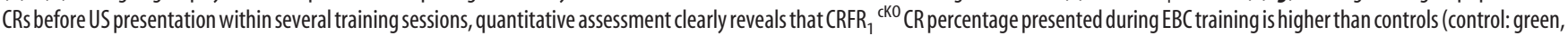
$\mathrm{CRFR}_{1}{ }^{{ }^{K} \mathrm{O} 0}$ : purple, $N=6,10$, respectively; $p=0.002$ ). CR timing histograms for session 10 are presented in Figure 6-1 (available at https://doi.org/10.1523/JNEUROSCI.3106-15.2018.f6-1. Similar learning trends are seen for CRFR ${ }_{1}{ }^{\text {KKO }}$ and control mice trained with 250 ms interstimulus interval in Figure 6-2 (available at https://doi.org/10.1523/JNEUROSCI.3106-15.2018.f6-2). Data are represented as mean \pm SEM. ${ }^{* * *} p<0.005$.

\section{Discussion}

CRF and its type 1 receptor, $\mathrm{CRFR}_{1}$, are well characterized stress response mediators; however, their role outside the limbic system is largely overlooked. Although $\mathrm{CRFR}_{1}$ expression in the cerebellum and in GrCs specifically has been reported previously, its role in cerebellar functions has not yet been examined (Van Pett et al., 2000; Justice et al., 2008). In this study, we established a GrCspecific $\mathrm{CRFR}_{1}{ }^{\mathrm{KO}}$ mouse line that was lacking most of the $\mathrm{CRFR}_{1}$ expressed in the cerebellum. We revealed that $\mathrm{CRFR}_{1}$ expressed in GrCs plays a relevant role in cerebellum-related learning at both the cellular and behavioral level, but not in motor performance- or stress-related behaviors.

\section{$\mathrm{CRFR}_{1}$ control of GrCs alters cerebellar learning}

GrCs depleted of $\mathrm{CRFR}_{1}$ showed a profoundly altered intrinsic excitability. The GrCs in $\mathrm{CRFR}_{1}{ }^{\mathrm{CKO}}$ mice showed rapid activation of firing and a reduced ability to maintain activation when the injected current was intense. This was apparently due to a progressive reduction of AHP and, consequently, to action potential inactivation. These alterations point to inefficiency of $\mathrm{Ca}^{2+}$ dependent mechanisms controlling AHP. Indeed, the firing pattern alterations are very similar to those induced by selective $\mathrm{BK}$-channel blockers and $\mathrm{N}$-type $\mathrm{Ca}^{2+}$ channel blockers in these neurons, which could stem from reduced expression of the $\mathrm{Ca}^{2+}$ ATPase (Fig. 3 and 5) (D'Angelo et al., 1998). Changes in basal calcium would bring $\mathrm{Ca}^{2+}$-binding sites of $\mathrm{BK}$ channels toward saturation and may contribute to inactivate $\mathrm{Ca}^{2+}$ channels (D’Angelo et al., 1998; for GrCs, see Rossi et al., 1998) both limiting the dynamic control of ionic channel gating normally triggered by $\mathrm{Ca}^{2+}$ entry during action potentials. We have also found that GrCs of $\mathrm{CRFR}_{1}{ }^{\mathrm{cKO}}$ fail to present LTP after TBS. This is particularly interesting considering that enhanced mossy fiber to $\mathrm{GrC}$ LTP results in impaired cerebellar learning at the behavioral level (Andreescu et al., 2011), whereas CRFR ${ }_{1}{ }^{c K O}$ mice show accelerated EBC at the behavioral level. Because LTP and LTD occur spontaneously in vivo, it would be interesting to try to shift GrCs to induce more LTD in freely behaving mice during the process of learning.

$\mathrm{CRFR}_{1}$ has been implicated in a variety of learning paradigms such as fear conditioning and spatial learning. Interestingly, fear conditioning is generally associated with increased CRFR 1 activity, but spatial and other reward-based forms of learning can be accelerated or disrupted by stress or CRFR 1 activity (Wang et al., 2011; Sztainberg and Chen, 2012; Santarelli et al., 2014; Campbell et al., 2015). Several studies have specifically shown that depletion of $\mathrm{CRFR}_{1}$ in rodents can "rescue" animals from the hazard- 
a

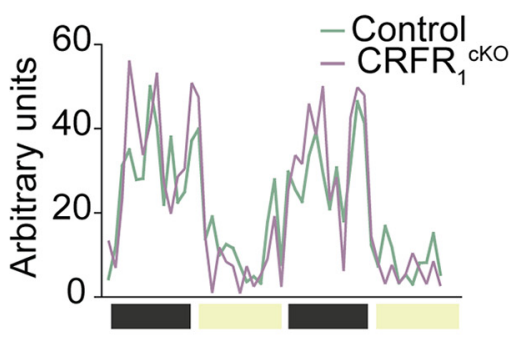

b

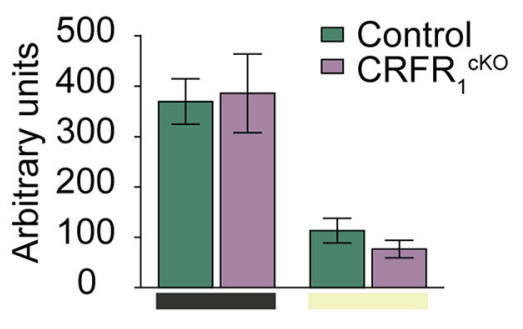

C

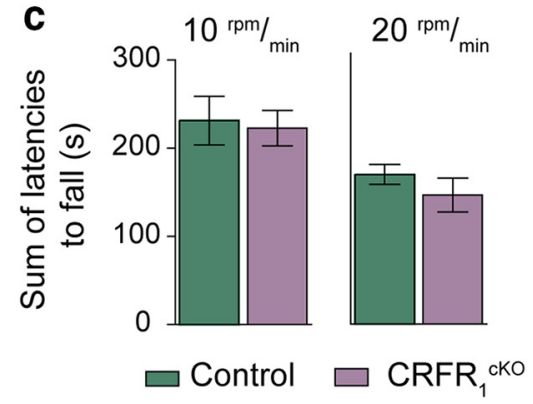

d
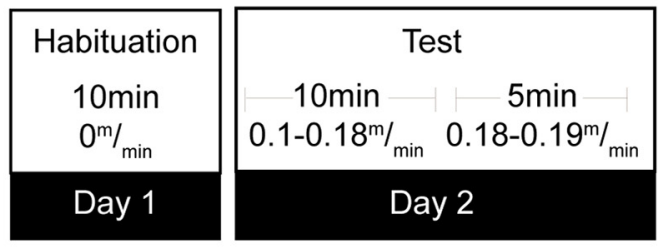

e

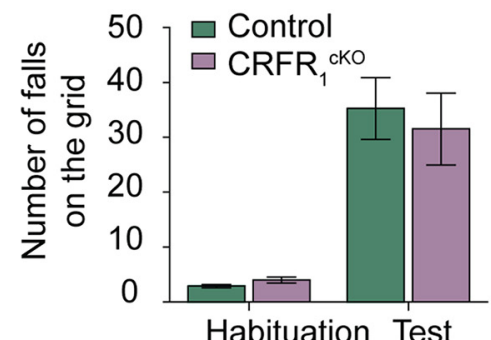

$\mathbf{f}$

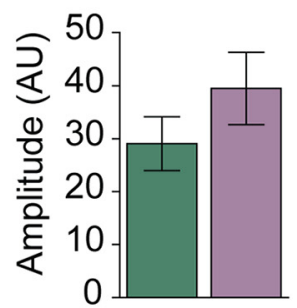

Startle response
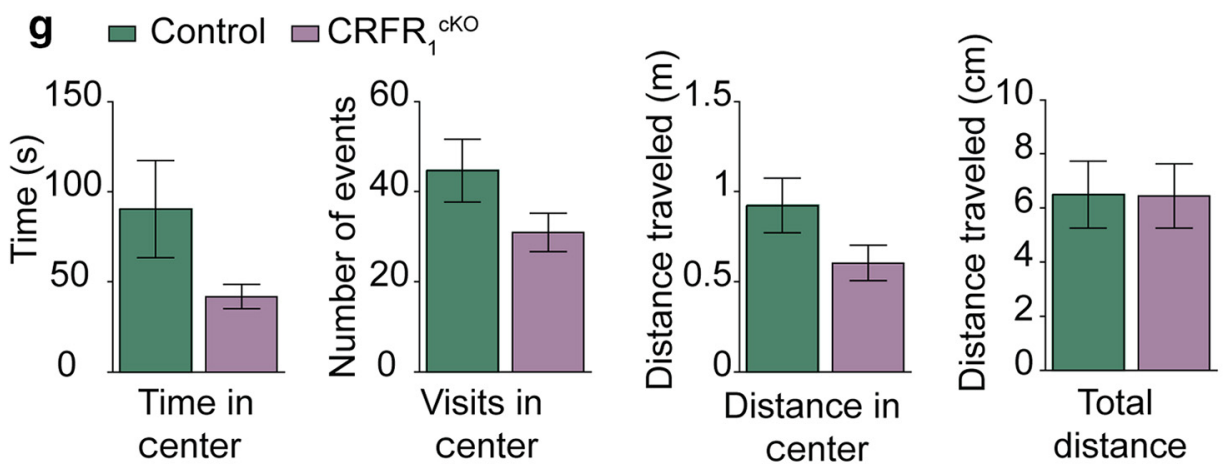

$\mathbf{h}$

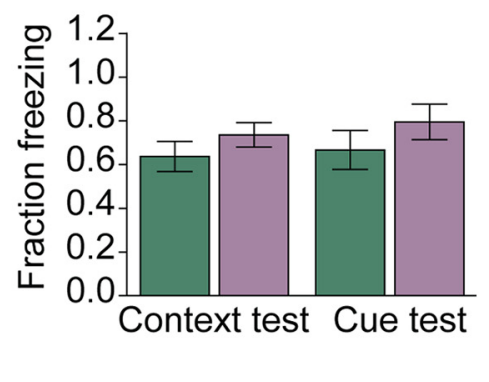

Figure 7. $\mathrm{CRFR}_{1}{ }^{\mathrm{C} 0}$ mice do not show any motor phenotype under challenging or neutral conditions. $\boldsymbol{a}, \boldsymbol{b}$, Home cage locomotion measured in single-caged CRFR ${ }_{1}{ }^{\mathrm{K} 0} \mathrm{mice}{ }^{2}$ and control mice did not reveal any differences between the groups in light or dark phases $\left(N=7,6 ; p=0.607,0.289\right.$, respectively). c, Mice tested on the rotarod for a single session ( 4 trials) at $10^{\mathrm{rpm}} / \mathrm{min}$ or $20 \mathrm{rpm} / \mathrm{min}$ (from 0 to $40 \mathrm{rpm}$ in 4 or $2 \mathrm{~min}$ ) lasted for similar latencies on the $\operatorname{rod}(10 \mathrm{rpm}: N=12,21 ; p=0.653 ; 20 \mathrm{rpm}: N=13,9 ; p=0.171$ ). $\boldsymbol{d}$, Layout of treadmill protocol. $\boldsymbol{e}$, Mice tested on a treadmill fell onto the grid to a similar extent $\left(N=12,10, p=0.849\right.$. $\boldsymbol{f}-\boldsymbol{h}, \mathrm{CRFR}_{1}{ }^{\mathrm{CKO} 0}$ and control mice do not show a fear- or anxiety-related phenotype. $\boldsymbol{f}$, Mice do not exhibit differences in startle response $(N=13,15 ; p=0.242) . \boldsymbol{g}, \mathrm{CRFR}_{1}{ }^{\mathrm{C} 0}$ and control mice tested in the open-field test do not show a significant difference in time spent in the center of the arena, number of visits to or distance in the center, or in total distance walked during the task ( $N=14,14 ; p=0.11-0.9)$. $\boldsymbol{h}$, After fear conditioning, $\mathrm{CRFR}_{1}{ }^{\mathrm{k} 0}$ and control mice did not show differences in freezing during cue $(N=6,4 ; p=$ 0.332 ) or context $(N=6,6 ; p=0.289)$ presentation. Data are represented as mean \pm SEM.

ous effect of early life stress or prolonged stress on learning (Joëls and Baram, 2009; Wang et al., 2011; Campbell et al., 2015). In humans, stress is reported to disrupt EBC (Wolf et al., 2009, 2012; Schwabe and Wolf, 2010). Consistent with this, mice lacking $\mathrm{CRFR}_{1}$ in $\mathrm{GrCs}$ show accelerated EBC learning.

\section{Potential beneficiary effects of $\mathrm{CRFR}_{1}$ activation at the acute stage}

If long-term processes, like some forms of procedural and declarative memory formation, are indeed impaired by activation of the $\mathrm{CRF}_{\text {CRFR }}$ system, then one might expect from a teleological point of view that other, more acute stress-related functions are enhanced. Several findings in the eye-blink field support this possibility. The more acute short-latency responses or startle responses induced by loud tones, when used as a CS for example (Medina et al., 2000; Boele et al., 2010), may well be enhanced by CRF. The mechanisms underlying such acutely enhanced responses might also explain why pharmacological injection of CRF into the lateral ventricles generates an unnaturally high level of responses at the early stage of the conditioning process (Servatius et al., 2005). Similarly, previous reports of stress-induced accelerated EBC in rats and mice present unusually fast learning (albeit different apparatus used; EMG and para-orbital shock) and show involvement of extracerebellar brain structures including the amygdala and the hippocampus (Shors et al., 1992; Weiss et al., 2005; Bangasser and Shors, 2007; Boele et al., 2010). The use of para-orbital shock is likely to generate a much more stressful learning environment that may lead to faster learning dependent more upon extracerebellar structures. Therefore, the CRF/CRFR operations may in particular contribute to acute stress-related functions at the cost of longer-term processes including some forms of procedural and declarative memory formation. Hopefully, future studies will give more insight about the specific role of stress-related peptides, including $\mathrm{CRFR}_{1}$, on various forms and aspects of learning.

For EBC to appear, distributed plasticity mechanisms involving multiple synaptic sites both in the cerebellar cortex and DCN must take place (Gao et al., 2012; ten Brinke et al., 2015). The mossy fiber input pathway engages a varied set of plasticity mechanisms in the whole cerebellum (Roggeri et al., 2008; Diwakar et al., 2011; Ramakrishnan et al., 2016), possibly as a result of in- 
creased excitability of the GrCs with a lower activation threshold. Downstream, this would lead to an increase in LTP of the parallel fiber to molecular layer interneuron synapses, more widespread LTD at the parallel fiber to PC synapse (ten Brinke et al., 2015), and more amplification of the recurrent nucleocortical pathway (Gao et al., 2016), all of which would facilitate learning at the behavioral level. This hard-wired plasticity occurs over the course of several days and may well be facilitated by the trophic activity requiring steroid mechanisms (Brandoli et al., 1998, 1998; Swinny et al., 2004; Jeanneteau and Chao, 2013). Interestingly, CRFR 1 is also expressed in the cerebellar nuclei, so the CRF released from the mossy fiber and/or climbing fiber collaterals may also affect the activity of neurons at this site (Errico and Barmack, 1993; Van Pett et al., 2000; Justice et al., 2008). Therefore, it would be interesting to further consider the effect of CRF from the mossy fibers on the cerebellar nuclei and explore to what extent its effects follow the concept of downregulation of associative learning induced by stress and/or upregulation of CRs through trophic activity.

\section{CRF control of cerebellar GrCs is not essential for baseline motor performance or anxiety-like behaviors}

Under basal conditions, motor performance tasks are not altered in $\mathrm{CRFR}_{1}{ }^{\mathrm{CKO}}$ mice. Indeed, the majority of GrCs are probably essential for motor learning rather than performance (Gao et al., 2012; Galliano et al., 2013). This is consistent with the cortical cerebellar conditioning model described by Yeo and Hesslow (1998) suggesting that the mossy fiber to GrC pathway conveys mainly cortical sensory information to the cerebellar cortex, which is essential for conditioning (Yeo and Hesslow, 1998). Moreover, despite its well characterized role in anxiety-related behavioral responses, cerebellar-specific manipulation of $\mathrm{CRFR}_{1}$ did not result in anxiety-like phenotype in our study (Elliott et al., 2010; Regev et al., 2011, 2012; Sztainberg and Chen, 2012; Lucas et al., 2013; Henckens et al., 2016). It is indeed possible that, in some brain regions such as the cerebellum, the CRF system is used for functions that are stress independent, so manipulation of these components will not yield an anxiety-related phenotype nor will they be affected by stressful stimuli or challenge. However, we suggest that the cerebellum adaptation to stressful challenges may be directed by $\mathrm{CRF} / \mathrm{CRFR}_{1}$ activity. Further research is needed to conclude whether cerebellar CRF is affected by stress or may affect stress coping in relation to cerebellar functions.

To conclude, we have presented strong evidence that $\mathrm{CRFR}_{1}$ in GrCs plays a specific role in cerebellar learning, but does not affect baseline motor performance, consistent with current understanding of GrCs function. On the cellular level, gene expression and electrophysiology revealed that functional $\mathrm{CRFR}_{1}$ is important in maintaining appropriate levels of excitability and calcium-pathway-related transcripts. The interaction between stress and various forms of learning has been researched extensively; however, cerebellar learning has been mostly neglected in this regard. Understanding how stressful emotional motivation can alter, not only emotional memories, but also motor learning will contribute to our understanding of CNS function both in general and under extreme conditions. $\mathrm{CRFR}_{1}$ undoubtedly has an important role in mediating such effects and its contribution to various cerebellar functions under different conditioning will hopefully be elucidated by future research.

\section{References}

Aller MI, Jones A, Merlo D, Paterlini M, Meyer AH, Amtmann U, Brickley S, Jolin HE, McKenzie AN, Monyer H, Farrant M, Wisden W (2003) Cer- ebellar granule cell cre recombinase expression. Genesis 36:97-103. CrossRef Medline

Andreescu CE, Prestori F, Brandalise F, D’Errico A, De Jeu MT, Rossi P, Botta L, Kohr G, Perin P, D’Angelo E, De Zeeuw CI (2011) NR2A subunit of the $\mathrm{N}$-methyl $\mathrm{d}$-aspartate receptors are required for potentiation at the mossy fiber to granule cell synapse and vestibulo-cerebellar motor learning. Neuroscience 176:274-283. CrossRef Medline

Armano S, Rossi P, Taglietti V, D’Angelo E (2000) Long-term potentiation of intrinsic excitability at the mossy fiber-granule cell synapse of rat cerebellum. J Neurosci 20:5208-5216. CrossRef Medline

Bangasser DA, Shors TJ (2007) The hippocampus is necessary for enhancements and impairments of learning following stress. Nat Neurosci 10: 1401-1403. CrossRef Medline

Batini C (1990) Cerebellar localization and colocalization of GABA and calcium binding protein-D28K. Arch Ital Biol 128:127-149. Medline

Bishop GA (1990) Neuromodulatory effects of corticotropin releasing factor on cerebellar Purkinje cells: an in vivo study in the cat. Neuroscience 39:251-257. CrossRef Medline

Bishop GA, Seelandt CM, King JS (2000) Cellular localization of corticotropin releasing factor receptors in the adult mouse cerebellum. Neuroscience 101:1083-1092. CrossRef Medline

Boele HJ, Koekkoek SK, De Zeeuw CI (2010) Cerebellar and extracerebellar involvement in mouse eyeblink conditioning: the ACDC model. Front Cell Neurosci 3:19. CrossRef Medline

Boele HJ, Koekkoek SK, De Zeeuw CI, Ruigrok TJ (2013) Axonal sprouting and formation of terminals in the adult cerebellum during associative motor learning. J Neurosci 33:17897-17907. CrossRef Medline

Brandoli C, Sanna A, De Bernardi MA, Follesa P, Brooker G, Mocchetti I (1998) Brain-derived neurotrophic factor and basic fibroblast growth factor downregulate NMDA receptor function in cerebellar granule cells. J Neurosci 18:7953-7961. CrossRef Medline

Campbell SN, Zhang C, Roe AD, Lee N, Lao KU, Monte L, Donohue MC, Rissman RA (2015) Impact of CRFR1 ablation on amyloid- $\beta$ production and accumulation in a mouse model of Alzheimer's disease. J Alzheimers Dis 45:1175-1184. CrossRef Medline

Chen A, Zorrilla E, Smith S, Rousso D, Levy C, Vaughan J, Donaldson C, Roberts A, Lee KF, Vale W (2006) Urocortin 2-deficient mice exhibit gender-specific alterations in circadian hypothalamus-pituitary-adrenal axis and depressive-like behavior. J Neurosci 26:5500-5510. CrossRef Medline

Chen Y, Brunson KL, Müller MB, Cariaga W, Baram TZ (2000) Immunocytochemical distribution of corticotropin-releasing hormone receptor type-1 (CRF(1))-like immunoreactivity in the mouse brain: light microscopy analysis using an antibody directed against the C-terminus. J Comp Neurol 420:305-323. CrossRef Medline

Cummings S, Sharp B, Elde R (1988) Corticotropin-releasing factor in cerebellar afferent systems: a combined immunohistochemistry and retrograde transport study. J Neurosci 8:543-554. CrossRef Medline

D’Angelo E, De Filippi G, Rossi P, Taglietti V (1995) Synaptic excitation of individual rat cerebellar granule cells in situ: evidence for the role of NMDA receptors. J Physiol 484:397-413. CrossRef Medline

D’Angelo E, De Filippi G, Rossi P, Taglietti V (1998) Ionic mechanism of electroresponsiveness in cerebellar granule cells implicates the action of a persistent sodium current. J Neurophysiol 80:493-503. CrossRef Medline

D’Angelo E, Rossi P, Armano S, Taglietti V (1999) Evidence for NMDA and mGlu receptor-dependent long-term potentiation of mossy fiber-granule cell transmission in rat cerebellum. J Neurophysiol 81:277-287. CrossRef Medline

De Zeeuw CI, Yeo CH (2005) Time and tide in cerebellar memory formation. Curr Opin Neurobiol 15:667-674. CrossRef Medline

De Zeeuw CI, Simpson JI, Hoogenraad CC, Galjart N, Koekkoek SK, Ruigrok TJ (1998) Microcircuitry and function of the inferior olive. Trends Neurosci 21:391-400. CrossRef Medline

Diwakar S, Lombardo P, Solinas S, Naldi G, D’Angelo E (2011) Local field potential modeling predicts dense activation in cerebellar granule cells clusters under LTP and LTD control. PLoS One 6:e21928. CrossRef Medline

Dobin A, Davis CA, Schlesinger F, Drenkow J, Zaleski C, Jha S, Batut P, Chaisson M, Gingeras TR (2013) STAR: ultrafast universal RNA-seq aligner. Bioinformatics 29:15-21. CrossRef Medline

Elliott E, Ezra-Nevo G, Regev L, Neufeld-Cohen A, Chen A (2010) Resilience to social stress coincides with functional DNA methylation of the crf gene in adult mice. Nat Neurosci 13:1351-1353. CrossRef Medline 
Errico P, Barmack NH (1993) Origins of cerebellar mossy and climbing fibers immunoreactive for corticotropin-releasing factor in the rabbit. J Comp Neurol 336:307-320. CrossRef Medline

Fadok JP, Krabbe S, Markovic M, Courtin J, Xu C, Massi L, Botta P, Bylund K, Müller C, Kovacevic A, Tovote P, Lüthi A (2017) A competitive inhibitory circuit for selection of active and passive fear responses. Nature 542: 96-100. CrossRef Medline

Farook JM, Wang Q, Moochhala SM, Zhu ZY, Lee L, Wong PT (2004) Distinct regions of periaqueductal gray (PAG) are involved in freezing behavior in hooded PVG rats on the cat-freezing test apparatus. Neurosci Lett 354:139-142. CrossRef Medline

Foote SL, Cha CI (1988) Distribution of corticotropin-releasing-factor-like immunoreactivity in brainstem of two monkey species (Saimiri sciureus and Macaca fascicularis): an immunohistochemical study. J Comp Neurol 276:239-264. CrossRef Medline

Galliano E, Gao Z, Schonewille M, Todorov B, Simons E, Pop AS, D'Angelo E, van den Maagdenberg AM, Hoebeek FE, De Zeeuw CI (2013) Silencing the majority of cerebellar granule cells uncovers their essential role in motor learning and consolidation. Cell Rep 3:1239-1251. CrossRef Medline

Gao Z, van Beugen BJ, De Zeeuw CI (2012) Distributed synergistic plasticity and cerebellar learning. Nat Rev Neurosci 13:619-635. CrossRef Medline

Gao Z, Proietti-Onori M, Lin Z, Ten Brinke MM, Boele HJ, Potters JW, Ruigrok TJ, Hoebeek FE, De Zeeuw CIzens(2016) Excitatory cerebellar nucleocortical circuit provides internal amplification during associative conditioning. Neuron 89:645-657. CrossRef Medline

Giovannucci A, Badura A, Deverett B, Najafi F, Pereira TD, Gao Z, Ozden I, Kloth AD, Pnevmatikakis E, Paninski L, De Zeeuw CI, Medina JF, Wang SS (2017) Cerebellar granule cells acquire a widespread predictive feedback signal during motor learning. Nat Neurosci 20:727-734 CrossRef Medline

Hansel C, Linden DJ, D’Angelo E (2001) Beyond parallel fiber LTD: the diversity of synaptic and non-synaptic plasticity in the cerebellum. Nat Neurosci 4:467-475. CrossRef Medline

Heinrichs SC, Koob GF (2004) Corticotropin-releasing factor in brain: a role in activation, arousal, and affect regulation. J Pharmacol Exp Ther 311:427-440. CrossRef Medline

Henckens MJ, Deussing JM, Chen A (2016) Region-specific roles of the corticotropin-releasing factor-urocortin system in stress. Nat Rev Neurosci 17:636-651. CrossRef Medline

Jeanneteau F, Chao MV (2013) Are BDNF and glucocorticoid activities calibrated? Neuroscience 239:173-195. CrossRef Medline

Joëls M, Baram TZ (2009) The neuro-symphony of stress. Nat Rev Neurosci 10:459-466. CrossRef Medline

Joëls M, Pu Z, Wiegert O, Oitzl MS, Krugers HJ (2006) Learning under stress: how does it work? Trends Cogn Sci 10:152-158. CrossRef Medline

Justice NJ, Yuan ZF, Sawchenko PE, Vale W (2008) Type 1 corticotropinreleasing factor receptor expression reported in BAC transgenic mice: implications for reconciling ligand-receptor mismatch in the central corticotropin-releasing factor system. J Comp Neurol 511:479-496. CrossRef Medline

Koekkoek SK, Den Ouden WL, Perry G, Highstein SM, De Zeeuw CI (2002) Monitoring kinetic and frequency-domain properties of eyelid responses in mice with magnetic distance measurement technique. J Neurophysiol 88:2124-2133. CrossRef Medline

Koekkoek SK, Hulscher HC, Dortland BR, Hensbroek RA, Elgersma Y, Ruigrok TJ, De Zeeuw CI (2003) Cerebellar LTD and learningdependent timing of conditioned eyelid responses. Science 301:17361739. CrossRef Medline

Koob GF, Heinrichs SC (1999) A role for corticotropin releasing factor and urocortin in behavioral responses to stressors. Brain Res 848:141-152. CrossRef Medline

Kühne C, Puk O, Graw J, Hrabě de Angelis M, Schütz G, Wurst W, Deussing JM (2012) Visualizing corticotropin-releasing hormone receptor type 1 expression and neuronal connectivities in the mouse using a novel multifunctional allele. J Comp Neurol 520:3150-3180. CrossRef Medline

Libster AM, Title B, Yarom Y (2015) Corticotropin-releasing factor increases Purkinje neuron excitability by modulating sodium, potassium, and Ih currents. J Neurophysiol 114:3339-3350. CrossRef Medline

Love MI, Huber W, Anders S (2014) Moderated estimation of fold change and dispersion for RNA-seq data with DESeq2. Genome Biol 15:550. CrossRef Medline

Lucas M, Chen A, Richter-Levin G (2013) Hypothalamic corticotropin- releasing factor is centrally involved in learning under moderate stress. Neuropsychopharmacology 38:1825-1832. CrossRef Medline

Madisen L, Zwingman TA, Sunkin SM, Oh SW, Zariwala HA, Gu H, Ng LL, Palmiter RD, Hawrylycz MJ, Jones AR, Lein ES, Zeng H (2010) A robust and high-throughput cre reporting and characterization system for the whole mouse brain. Nat Neurosci 13:133-140. CrossRef Medline

Mapelli L, Solinas S, D’Angelo E (2016) Corrigendum: Integration and regulation of glomerular inhibition in the cerebellar granular layer circuit. Front Cell Neurosci 10:31. CrossRef Medline

Medina JF, Nores WL, Ohyama T, Mauk MD (2000) Mechanisms of cerebellar learning suggested by eyelid conditioning. Curr Opin Neurobiol 10:717-724. CrossRef Medline

Merchenthaler I (1984) Corticotropin releasing factor (CRF)-like immunoreactivity in the rat central nervous system: extrahypothalamic distribution. Peptides 5 Suppl 1:53-69. Medline

Miyata M, Okada D, Hashimoto K, Kano M, Ito M (1999) Corticotropinreleasing factor plays a permissive role in cerebellar long-term depression. Neuron 22:763-775. CrossRef Medline

Neher E (1992) Correction for liquid junction potentials in patch clamp experiments. Methods Enzymol 207:123-131. CrossRef Medline

Neufeld-Cohen A, Tsoory MM, Evans AK, Getselter D, Gil S, Lowry CA, Vale WW, Chen A (2010) A triple urocortin knockout mouse model reveals an essential role for urocortins in stress recovery. Proc Natl Acad Sci U S A 107:19020-19025. CrossRef Medline

Olschowka JA, O’Donohue TL, Mueller GP, Jacobowitz DM (1982) Hypothalamic and extrahypothalamic distribution of CRF-like immunoreactive neurons in the rat brain. Neuroendocrinology 35:305-308. CrossRef Medline

Prestori F, Bonardi C, Mapelli L, Lombardo P, Goselink R, De Stefano ME, Gandolfi D, Mapelli J, Bertrand D, Schonewille M, De Zeeuw C, D'Angelo E (2013) Gating of long-term potentiation by nicotinic acetylcholine receptors at the cerebellum input stage. PLoS One 8:e64828. CrossRef Medline

Prestori F, Rossi P, Bearzatto B, Lainé J, Necchi D, Diwakar S, Schiffmann SN, Axelrad H, D'Angelo E (2008) Altered neuron excitability and synaptic plasticity in the cerebellar granular layer of juvenile prion protein knockout mice with impaired motor control. J Neurosci 28:7091-7103. CrossRef Medline

Ramakrishnan KB, Voges K, De Propris L, De Zeeuw CI, D’Angelo E (2016) Tactile stimulation evokes long-lasting potentiation of Purkinje cell discharge in vivo. Front Cell Neurosci 10:36. CrossRef Medline

Refojo D, Schweizer M, Kuehne C, Ehrenberg S, Thoeringer C, Vogl AM, Dedic N, Schumacher M, von Wolff G, Avrabos C, Touma C, Engblom D, Schütz G, Nave KA, Eder M, Wotjak CT, Sillaber I, Holsboer F, Wurst W, Deussing JM (2011) Glutamatergic and dopaminergic neurons mediate anxiogenic and anxiolytic effects of CRHR1. Science 333:1903-1907. CrossRef Medline

Regev L, Neufeld-Cohen A, Tsoory M, Kuperman Y, Getselter D, Gil S, Chen A (2011) Prolonged and site-specific over-expression of corticotropinreleasing factor reveals differential roles for extended amygdala nuclei in emotional regulation. Mol Psychiatry 16:714-728. CrossRef Medline

Regev L, Tsoory M, Gil S, Chen A (2012) Site-specific genetic manipulation of amygdala corticotropin-releasing factor reveals its imperative role in mediating behavioral response to challenge. Biol Psychiatry 71:317-326. CrossRef Medline

Roggeri L, Rivieccio B, Rossi P, D'Angelo E (2008) Tactile stimulation evokes long-term synaptic plasticity in the granular layer of cerebellum. J Neurosci 28:6354-6359. CrossRef Medline

Rossi P, De Filippi G, Armano S, Taglietti V, D’Angelo E (1998) The weaver mutation causes a loss of inward rectifier current regulation in premigratory granule cells of the mouse cerebellum. J Neurosci 18:3537-3547. CrossRef Medline

Sánchez MM, Young LJ, Plotsky PM, Insel TR (1999) Autoradiographic and in situ hybridization localization of corticotropin-releasing factor 1 and 2 receptors in nonhuman primate brain. J Comp Neurol 408:365-377. CrossRef Medline

Santarelli S, Lesuis SL, Wang XD, Wagner KV, Hartmann J, Labermaier C, Scharf SH, Müller MB, Holsboer F, Schmidt MV (2014) Evidence supporting the match/mismatch hypothesis of psychiatric disorders. Eur Neuropsychopharmacol 24:907-918. CrossRef Medline

Schmolesky MT, De Ruiter MM, De Zeeuw CI, Hansel C (2007) The neuropeptide corticotropin-releasing factor regulates excitatory transmission 
and plasticity at the climbing fibre-Purkinje cell synapse. Eur J Neurosci 25:1460-1466. CrossRef Medline

Schwabe L, Wolf OT (2010) Learning under stress impairs memory formation. Neurobiol Learn Mem 93:183-188. CrossRef Medline

Seja P, Schonewille M, Spitzmaul G, Badura A, Klein I, Rudhard Y, Wisden W, Hübner CA, De Zeeuw CI, Jentsch TJ (2012) Raising cytosolic cl- in cerebellar granule cells affects their excitability and vestibulo-ocular learning. EMBO J 31:1217-1230. CrossRef Medline

Servatius RJ, Beck KD, Moldow RL, Salameh G, Tumminello TP, Short KR (2005) A stress-induced anxious state in male rats: corticotropinreleasing hormone induces persistent changes in associative learning and startle reactivity. Biol Psychiatry 57:865-872. CrossRef Medline

Sgritta M, Locatelli F, Soda T, Prestori F, D’Angelo EU (2017) Hebbian spike-timing dependent plasticity at the cerebellar input stage. J Neurosci 37:2809-2823. CrossRef Medline

Shors TJ, Weiss C, Thompson RF (1992) Stress-induced facilitation of classical conditioning. Science 257:537-539. CrossRef Medline

Swinny JD, Metzger F, IJkema-Paassen J, Gounko NV, Gramsbergen A, van der Want JJ (2004) Corticotropin-releasing factor and urocortin differentially modulate rat Purkinje cell dendritic outgrowth and differentiation in vitro. Eur J Neurosci 19:1749-1758. CrossRef Medline

Sztainberg Y, Chen A (2012) Neuropeptide regulation of stress-induced behavior: insights from the CRF/urocortin family. In: Handbook of neuroendocrinology (Fink G, Pfaff DW, Levine JE, eds), pp 355-375. San Diego, CA: Academic.

ten Brinke MM, Boele HJ, Spanke JK, Potters JW, Kornysheva K, Wulff P, IJpelaar AC, Koekkoek SK, De Zeeuw CI (2015) Evolving models of Pavlovian conditioning: cerebellar cortical dynamics in awake behaving mice. Cell Rep 13:1977-1988. CrossRef Medline

Treweek JB, Chan KY, Flytzanis NC, Yang B, Deverman BE, Greenbaum A, Lignell A, Xiao C, Cai L, Ladinsky MS, Bjorkman PJ, Fowlkes CC, Gradi- naru V (2015) Whole-body tissue stabilization and selective extractions via tissue-hydrogel hybrids for high-resolution intact circuit mapping and phenotyping. Nat Protoc 10:1860-1896. CrossRef Medline

Van Pett K, Viau V, Bittencourt JC, Chan RK, Li HY, Arias C, Prins GS, Perrin M, Vale W, Sawchenko PE (2000) Distribution of mRNAs encoding CRF receptors in brain and pituitary of rat and mouse. J Comp Neurol 428:191-212. CrossRef Medline

Wang XD, Rammes G, Kraev I, Wolf M, Liebl C, Scharf SH, Rice CJ, Wurst W, Holsboer F, Deussing JM, Baram TZ, Stewart MG, Müller MB, Schmidt MV (2011) Forebrain CRF1 modulates early-life stress-programmed cognitive deficits. J Neurosci 31:13625-13634. CrossRef Medline

Weiss C, Sametsky E, Sasse A, Spiess J, Disterhoft JF (2005) Acute stress facilitates trace eyeblink conditioning in C57BL/6 male mice and increases the excitability of their CA1 pyramidal neurons. Learn Mem 12:138-143. CrossRef Medline

Wolf OT, Minnebusch D, Daum I (2009) Stress impairs acquisition of delay eyeblink conditioning in men and women. Neurobiol Learn Mem 91: 431-436. CrossRef Medline

Wolf OT, Bauser DS, Daum I (2012) Eyeblink conditional discrimination learning in healthy young men is impaired after stress exposure. Psychophysiology 49:164-171. CrossRef Medline

Xiao J, Gong S, Ledoux MS (2007) Caytaxin deficiency disrupts signaling pathways in cerebellar cortex. Neuroscience 144:439-461. CrossRef Medline

Ye L, Allen WE, Thompson KR, Tian Q, Hsueh B, Ramakrishnan C, Wang AC, Jennings JH, Adhikari A, Halpern CH, Witten IB, Barth AL, Luo L, McNab JA, Deisseroth K (2016) Wiring and molecular features of prefrontal ensembles representing distinct experiences. Cell 165:1776-1788. CrossRef Medline

Yeo CH, Hesslow G (1998) Cerebellum and conditioned reflexes. Trends Cogn Sci 2:322-330. CrossRef Medline 